\title{
Assessment of Age, Diet, and Growth of Yellow Perch ( Perca flavescens) in Cheat Lake, West Virginia
}

Nate Taylor

West Virginia University

Follow this and additional works at: https://researchrepository.wvu.edu/etd

\section{Recommended Citation}

Taylor, Nate, "Assessment of Age, Diet, and Growth of Yellow Perch ( Perca flavescens) in Cheat Lake, West Virginia" (2013). Graduate Theses, Dissertations, and Problem Reports. 211.

https://researchrepository.wvu.edu/etd/211

This Thesis is protected by copyright and/or related rights. It has been brought to you by the The Research Repository @ WVU with permission from the rights-holder(s). You are free to use this Thesis in any way that is permitted by the copyright and related rights legislation that applies to your use. For other uses you must obtain permission from the rights-holder(s) directly, unless additional rights are indicated by a Creative Commons license in the record and/ or on the work itself. This Thesis has been accepted for inclusion in WVU Graduate Theses, Dissertations, and Problem Reports collection by an authorized administrator of The Research Repository @ WVU. For more information, please contact researchrepository@mail.wvu.edu. 


\title{
Assessment of Age, Diet, and Growth of Yellow Perch (Perca flavescens) in
} Cheat Lake, West Virginia

\author{
Nate Taylor \\ A Thesis Submitted to the \\ Davis College of Agriculture, Natural Resources, and Design \\ at West Virginia University \\ in partial fulfillment of the requirements \\ for the degree of \\ Master of Science \\ in \\ Wildlife and Fisheries Resources
}

Stuart A. Welsh, Ph.D., Chair

Kyle J. Hartman, Ph.D.

David I. Wellman, M.S.

Division of Forestry and Natural Resources

Morgantown, WV

2013

Keywords: Perca flavescens, yellow perch, age, diet, growth model, Cheat Lake 


\section{ABSTRACT \\ Assessment of Age, Diet, and Growth of Yellow Perch (Perca flavescens) in Cheat Lake, West Virginia}

\section{Nate D. Taylor}

This thesis evaluates population characteristics of yellow perch (Perca flavescens) in Cheat Lake, West Virginia, and is comprised of two chapters: 1) an introduction and literature review on the biology, ecology, and life history of yellow perch and studies regarding diet growth, and condition and 2) a study examining age and length, summer diet composition, and growth of yellow perch in Cheat Lake, West Virginia. Owing partly to recent mitigation of acidic conditions in the Cheat River watershed, populations of yellow perch and other fishes have increased in Cheat Lake. For this study, I evaluated age and length, summer diet composition, and growth for Cheat Lake yellow perch, providing useful information for management of the fishery. The sample ( $\mathrm{n}=271)$ included individuals of a wide range of ages (0-9) and sizes (66-320 $\mathrm{mm})$. Gender-specific differences in growth rate were observed beginning at Age-2. Females grew faster and attained larger maximum sizes than males. An information theoretic approach was taken to evaluate the applicability of various growth models. Four candidate models (von Bertalanffy, Gompertz, logistic, and power) were fitted to mean length-at-age data. The von Bertalanffy growth model was selected by AICc as the best approximating model, and data also provided some evidence supporting the Gompertz model. A combination of quantitative methods and multivariate statistics were used to evaluate differences in summer diet composition among Age-0, Age-1, and Age-2+ individuals. Ontogenetic diet shifts were observed. Zooplankton (primarily Copepods) was identified from all Age-0 individuals. Trichoptera and Chironomidae were the most important prey items for Age-1 yellow perch. Fishes were identified among the stomach contents from $41.5 \%$ of all Age-2+ individuals. Cheat Lake is one of a few reservoirs in West Virginia that supports a yellow perch fishery, and fishery-independent data from this study represent the first comprehensive assessment of this fishery. Baseline data for management and future stock assessments were provided by this investigation. 


\section{Acknowledgments}

I would like express my sincere gratitude toward my advisor, Dr. Stuart Welsh, for giving me the opportunity to pursue a master's degree doing something I truly love. The immense support and guidance he has provided is truly invaluable. I would like to thank my committee members, Dr. Kyle Hartman and Dave Wellman, for their professional advice and the time they have dedicated to my research. Also, I would like to extend a special "thank you" to Dustin Smith for his continued guidance, support, and the extensive amount of time and effort he devoted throughout both field and laboratory portions of my study. I would also like to thank Becky Nestor for her support and for keeping my project financially organized. Donna Hartman, Eric Miller, Eric Merriam, Brian Carlson and Corbin Hilling were also of tremendous help in various portions of my research. I would also like to acknowledge Dr. George Merovich for the assistance and advice he provided regarding statistical analyses.

My parents (Mark and Kelly) provided unconditional love an encouragement every step of the way. I would also like to thank my fiancée, Jessica, for her continued love and support. One cannot put a price on the constant reassurance and love I received from both family and friends throughout the entirety of my graduate career, and none of this would have been possible without them.

Lastly, I would like to acknowledge the West Virginia University Division of Forestry and Natural Resources and the USGS Cooperative Fish and Wildlife Research Unit for providing the necessary equipment and facilities for my research. Funding for this study was provided by the West Virginia Division of Natural Resources, and First Energy Corporation. This study was performed under the auspices of WVU-ACUC protocol \#10-0403. 


\section{Table of Contents}

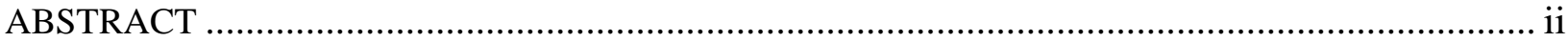

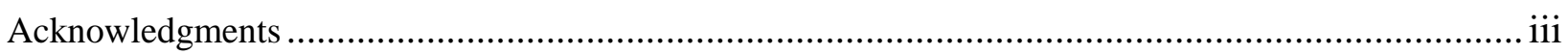

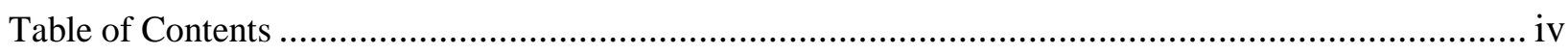

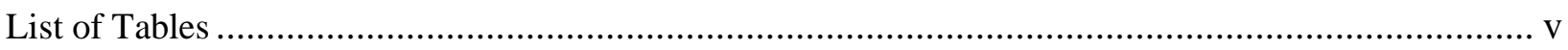

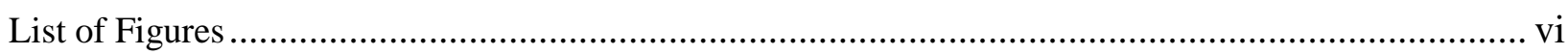

CHAPTER 1: Literature Review.......................................................................................... 1

Biology, Ecology, and Life History of Perca flavescens .........................................................1

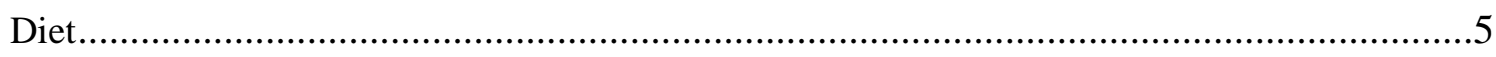

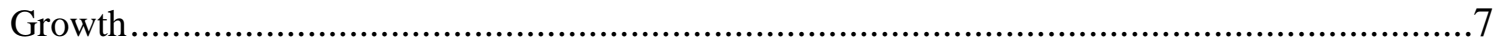

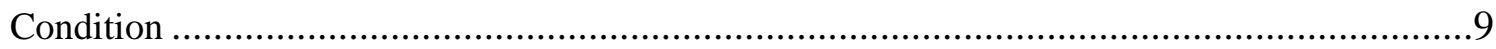

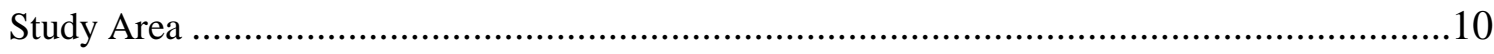

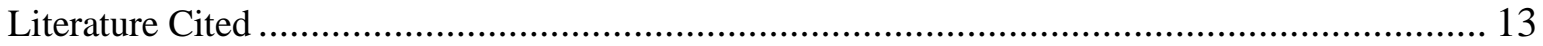

CHAPTER 2: Assessment of Age, Diet, and Growth of Yellow Perch in Cheat Lake, West Virginia .....21

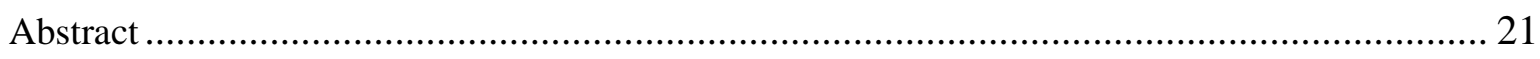

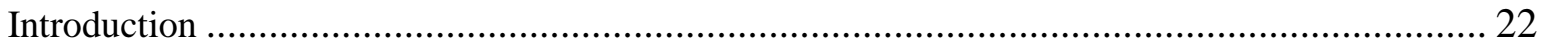

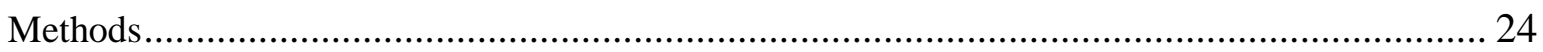

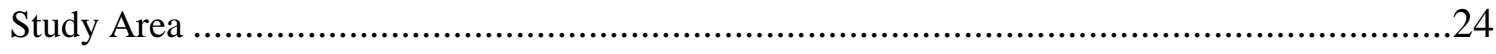

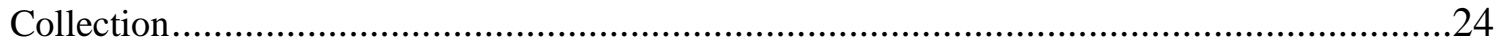

Evaluation of Sex, Size Structure, Age Structure, Mortality, and Condition..............................25

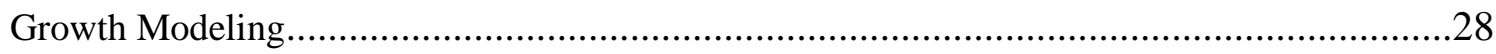

Comparative Analysis of Growth Rates .................................................................................31

Compositional Diet Analysis .........................................................................................31

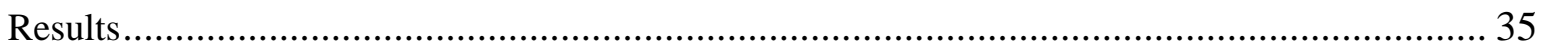

Evaluation of Sex, Size Structure, Age Structure, Mortality, and Condition................................35

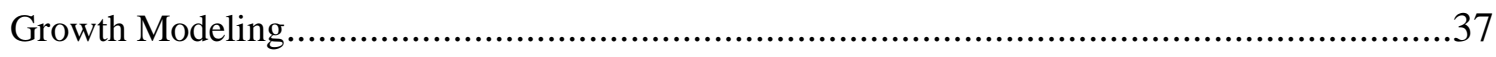

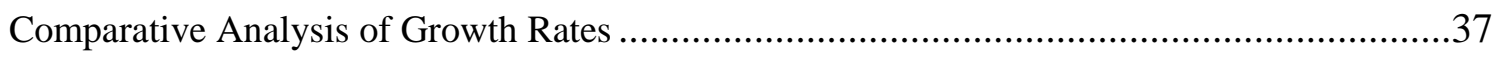

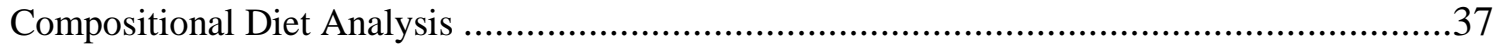

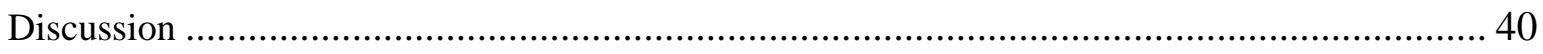

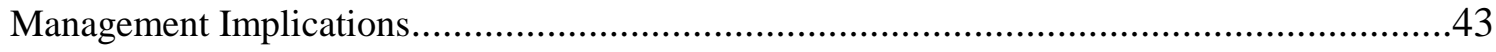

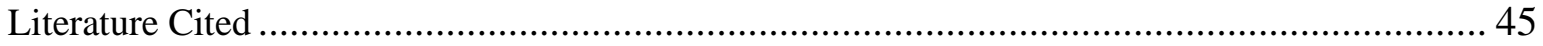




\section{List of Tables}

Table 1. Total number of individuals (n) and mean relative weight $\left(W_{r}\right)$ among Gabelhouse (1984) five-cell size categories.

Table 2. Number of estimated parameters ( $k$ ), Akaike's Information Criterion corrected for small sample size (AICc), Akaike differences $(\Delta)$, and Akaike weights ( $w$ ) for four candidate models. 55

Table 3. Parameter estimates and associated standard error (S. E.) for candidate models.

Table 4. Relative growth index applied to Cheat Lake yellow perch. Total number (n), standard length estimates $\left(L_{s}\right)$, mean length-at-age $(L)$, estimated relative growth values (RGI), and percentile are presented.

Table 5. Summary of summer diet composition among age groups of yellow perch $(\mathrm{n}=190)$. Data are presented as frequency of occurrence $\left(O_{i}\right)$, mean composition by number $\left(M N_{i}\right)$, and prey-specific abundance $\left(P_{i}\right)$. Yellow perch with empty stomachs and individuals containing unidentifiable prey items were excluded from diet analyses. 


\section{List of Figures}

Figure 1. Length-frequency distributions for male, female, and young-of-year (YOY) yellow perch from Cheat Lake, West Virginia $(n=271)$. Individuals grouped into 10

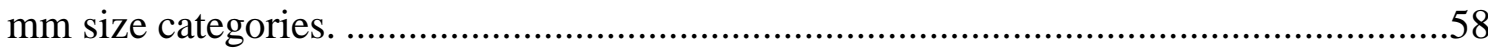

Figure 2. Histogram representing sex-specific distribution of ages among 271 Cheat

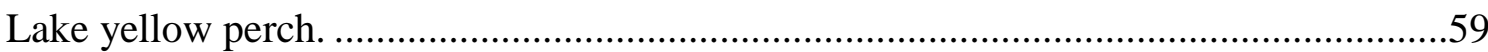

Figure 3. Residual plot (A) and weighted catch curve (B) fitted to number-at-age data for Cheat Lake yellow perch ages 2 to 9 .

Figure 4. Length-at-age data collected from 57 male (A) and 175 female (B) yellow perch of Age-1 or older.

Figure 5. Comparison of growth models fitted to mean length-at-age data from 271 Cheat Lake yellow perch.

Figure 6. Comparison between growth rates of Cheat Lake yellow perch to the standard growth model (Jackson et al. 2008) representing typically growth patterns observed among all North American populations. Parameter $\mathrm{t}_{0}$ constrained for fitted von Bertalanffy growth model for direct comparison.

Figure 7. Ordination of summer diet composition among age groups. Ellipses represent $95 \%$ confidence intervals of mean NMDS scores for age groups. 


\section{CHAPTER 1: Literature Review}

\section{Biology, Ecology, and Life History of Perca flavescens}

The yellow perch, Perca flavescens, is an economically important game species

throughout much of its extensive geographic distribution in the United States, targeted for both recreational and commercial fishing. A member of the family Percidae, the yellow perch is native to North America and was described by Samuel Latham Mitchill in 1814 from New York State (Jenkins and Burkhead 1993). Morphologically, the yellow perch can be identified by its yellow to brass-colored body with dark vertical bars on both sides (Brown et al. 2009). Typically, the lateral bars are a dark olive, and an orange hue is present on the margins of the fins (Jenkins and Burkhead 1993). The two dorsal fins are slightly separate: the first consisting of $12-14$ spines and the second (only 1-2 spines) is comprised almost entirely of rays (Scott and Crossman 1973; Jenkins and Burkhead 1993). Yellow perch are morphologically similar to the Eurasian perch, Perca fluviatilis (Jenkins and Burkhead 1993). However, anatomical and genetic differences support species level recognition (Collette and Banarescu 1977; Carney and Dick 1999).

The yellow perch, found only in North America, has a wide distribution owing, partially, to dispersal centered from the Mississippi River system following Pleistocene glaciation (McPhail and Lindsay 1970; Scott and Crossman 1973). Yellow perch display extensive habitat plasticity and tolerance to environmental changes, largely contributing to their vast distribution in North America (Jenkins and Burkhead 1993). Mansueti (1964) suggested that yellow perch are tolerant of saline waters, up to 5\% salinity. As a result, brackish waters of the Chesapeake Bay provide one of the most economically important commercial and recreational fisheries to the state of Maryland. Additionally, popularity as 
a game species has led to introductions of yellow perch throughout much of North America (Roberge et al. 2001; Brown et al. 2009). In the late $19^{\text {th }}$ and early $20^{\text {th }}$ centuries, the US Fish Commission introduced yellow perch into many waters of the western United States (Moyle 2002). Unauthorized introductions of yellow perch have also greatly expanded their distribution throughout North America.

Generally, male yellow perch achieve sexual maturity much earlier in life than do females (Brofka and Marsden 1993; Jenkins and Burkhead 1993; Moyle 2002). Additionally, latitudinal variation in maturation rate has been documented in yellow perch. In populations occurring at northern latitudes, males commonly achieved sexual maturity at between 2-3 years of age, while 3-4 years are typically required before maturation occurs in females (Becker 1983).

Yellow perch are iteroparous, and spawning occurs annually in the spring. Reproduction in yellow perch, as with most teleost fishes, is primarily governed by increasing water temperatures and photoperiod. Hokanson (1977) noted that spawning occurs at temperatures between 2.0 and $18.6^{\circ} \mathrm{C}$. Time of spawning fluctuates among water bodies, but generally occurs during late winter, at southern latitudes, and early summer, at northern latitudes (Jenkins and Burkhead 1993). Tsai and Gibson (1971) found that yellow perch eggs stored at temperatures between 8.5 and $10.0^{\circ} \mathrm{C}$ produce the highest rate of gamete viability. In a laboratory study conducted by Mansueti (1964), larval yellow perch emerged from eggs in roughly 27 days at temperatures between 8.5 and $12.0^{\circ} \mathrm{C}$. However, Roberge et al. (2001) suggested a much shorter incubation period of 8 to 10 days in Canadian lakes. 
Spawning behaviors of yellow perch have been documented across its wide geographic range. Spawning migrations are largely reduced in yellow perch, relative to other larger percids (Craig 2000). Yellow perch spawning typically occurs at night (Scott and Crossman 1973) in shallow water over macrophyte beds and submerged woody debris (Echo 1955; Muncy 1962; Nelson and Walburg 1977; Ney 1978; Becker 1983). Prior to spawning, the genital opening in female yellow perch becomes inflamed and distended (Parker 1942). Harrington (1947) suggested communal spawning behavior in yellow perch, observing more than 25 males in pursuit of a single female. Eggs are released in a long, semi-buoyant strand, typically draped over vegetation or submerged woody debris; a characteristic unique among all North American freshwater fishes (Robillard and Marsden 2007). Herman et al. (1959) noted that egg masses occasionally exceed $2 \mathrm{~m}$ in length and $7.5 \mathrm{~cm}$ in diameter. Thorpe (1977) suggested that the long strand of eggs may function as a predatory defense mechanism. Newsome and Tomkins (1985) proposed that the gelatinous encasement may contain a chemical toxin, reducing predation on eggs. Aeration of the eggs may be one problem associated with this form of reproduction (Robillard and Marsden 2007). However, Regier et al. (1969) acknowledged that semibuoyant properties may promote oxygenation of developing embryo when draped over submerged vegetation and brush. Failed reproductive efforts associated with physical damage to the developing embryos may be further reduced by securing egg strands to rooted structures (Regier et al. 1969). In the absence of structure, yellow perch have been observed dispersing eggs across larger substrates (Herman et al. 1959; Noble 1970; Smith 1986). Interstitial spaces between cobble, gravel, and boulders may increase aeration of eggs by permitting the flow of water (Robillard and Marsden 2007). 
The yellow perch is an excellent example of an r-selected species. No parental care is given, and females immediately evacuate the spawning area after releasing eggs (Jenkins and Burkhead 1993). Males temporarily remain near the eggs following fertilization; however, no evidence supports male protection of the eggs (Scott and Crossman 1973). Studies on fecundity have shown that the females produce between 2,000-157,000 eggs, largely dependent on the size and health of the female (Brazo et al. 1975; Hardy 1978). Scott and Crossman (1973) suggested an average egg mass of approximately 23,000 eggs.

Early ontogeny of yellow perch has been well documented. Hatching generally occurs when larvae reach 4.7 to $6.6 \mathrm{~mm}$ TL (Holland-Bartels et al. 1990; Fisher et al. 1998). Pectoral fins are partially formed at emergence; however, the rest of the fins are not formed until approximately $11.0 \mathrm{~mm}$ TL (Mansueti 1964). Although fins are generally not completely formed until approximately $21-27 \mathrm{~mm}$ TL, individuals are considered to be juveniles at $13 \mathrm{~mm}$ (Mansueti 1964). The characteristic vertical bars do not begin developing until $20 \mathrm{~mm}$ TL (Mansueti 1964). Scales of fishes develop in a unique, species-specific manner (Everhart 1949; Brown and Bailey 1952; Pycha and Smith, Jr. 1955). Pycha and Smith, Jr. (1955) noted that scales of the yellow perch begin developing near the caudal peduncle at $20 \mathrm{~mm}$ TL and continue to develop anteriorly along the lateral line. At approximately $24 \mathrm{~mm}$ TL, the first scales are fully imbricated, and individuals commonly exceed $36 \mathrm{~mm}$ TL before scales have fully formed (Pycha and Smith, Jr. 1955).

Exogenous feeding commences between 6 and $10 \mathrm{~mm}$ TL (Swindoll 1981; Hinshaw 1985; Whiteside et al. 1985; Fisher et al. 1998). Initially, the diet of yellow 
perch is largely restricted to zooplankton. However, expansion to new prey types occurs through ontogenetic shifts in the diet of maturing individuals (Parsons 1950; Scott 1955; Seaburg and Moyle 1964; Clady 1974; Keast 1977; Sandheinrich and Hubert 1984; Heath and Roff 1995; Parker et al. 2009). In small lakes, yellow perch are pelagic during the first 30-40 days of their life (Whiteside et al. 1985; Weber et al. 2011). As larval yellow perch develop past the pelagic life stage, they become demersal.

As a gregarious species, yellow perch form schools commonly segregated by size (Hasler and Bardach 1949; Sandheinrich and Hubert 1984) and sex (Jobes 1952; Wells and Jorgenson 1983; Sandheinrich and Hubert 1984). Adult yellow perch are shoaling predators, feeding on vulnerable prey items as they move along the littoral zone. Aggregate behaviors are most pronounced during daylight, with schools dissolving during hours of darkness and forming again the following morning (Hasler and Bardach 1949; Hasler and Villemonte 1953; Hasler and Hergenrader 1968; Helfman 1979; Sandheinrich and Hubert 1984). During warmer months, juveniles and small adults tend to school in the littoral zones of lakes and other shallow water, seeking refuge among vegetation and other structures (Herman et al. 1959). A preferred summer temperature has been suggested by Fergusson (1958) to be between 17.6 and $25.0^{\circ} \mathrm{C}$. Apart from most temperate species, yellow perch remain active throughout the winter months, making them a target species for ice fishing.

\section{Diet}

Ontogenetic diet changes of yellow perch have been documented by several authors: expanding from zooplankton, to benthic macroinvertebrates, and ending in piscivory (Parsons 1950; Scott 1955; Seaburg and Moyle 1964; Clady 1974; Keast 1977; 
Sandheinrich and Hubert 1984; Heath and Roff 1995; Parker et al. 2009). Little variation exists in the diet of larval fish, consisting primarily of algae and zooplankton (Noble 1975; Jenkins and Burkhead 1993; Brown et al. 2009). Ney and Smith (1975) suggest that the diet of larval yellow perch begins to expand to larger macroinvertebrates at roughly 30 mm TL. Juveniles are demersal, and diet is commonly comprised of aquatic insect larvae and other benthic macroinvertebrate species (Lott et al. 1996; Paukert and Willis 2001). Data from Eggers et al. (1978) suggest that larger individuals feed primarily on prey within the water column.

In contrast, yellow perch are commonly considered dietary generalists, implying an overlap in diet composition among individuals of various sizes. Knight et al. (1984) described yellow perch as 'opportunistic feeders', capable of utilizing various prey types. Results from Fullhart et al. (2002) indicated that piscine prey availability minimally affected diet composition of yellow perch when an extensive macroinvertebrate prey-base was present. Chironomid larvae have been recognized as principal dietary components among all age and size classes (Paxton and Stevenson 1978; Weisberg and Janicki 1990; Lott et al. 1996; Fullhart et al. 2002; Creque and Czesny 2012). Keast (1985) described the yellow perch as a secondary-piscivore, with $30-40 \%$ of the diet consisting of smaller fishes, including juvenile yellow perch. Cannibalistic behaviors are common, and Tarby (1974) suggested cannibalism to play a significant role in the population structure of yellow perch in Oneida Lake, New York.

Temporal variability in dietary composition has been documented, attributable to both seasonal and annual changes occurring within aquatic communities. Results from Paxton and Stevenson (1978) illustrated seasonal differences in the dietary transition of 
Age-0 yellow perch from two separate years. Wilkins et al. (2002) discovered seasonal variation in prey types consumed by three size-classes of yellow perch sampled between April and October. In western Lake Erie, adult yellow perch consumed macroinvertebrate prey during the spring, transitioning to a diet comprised primarily of other fishes, thereafter (Knight et al. 1984).

Foraging activities of yellow perch are strongly correlated to periods of high light intensity, contributing to diel foraging behaviors. Results from Hubert and Sandheinrich (1983) suggest that stomach fullness is typically highest during sunrise and sunset. Foraging behaviors in larval yellow perch are also directly influenced by light. Results from Mills et al. (1981) suggested that young yellow perch only consumed long-bodied Daphnia spp. during periods of low light; however, the same individuals began feeding on a diverse assemblage of smaller organisms as light intensity increased. Much of the diet in very young yellow perch consists of very small organisms, owing largely to gape limitation. At night, foraging activity is limited, and most yellow perch remain inactive on the bottom in shallow areas (Hasler and Villemonte 1953; Scott 1955).

\section{Growth}

Activities in the pituitary gland of fishes largely control processes associated with somatic growth and gonadal development through the production of thyrotropic and gonadotropic hormones (Joblin 1995). Hormonal production, directly influencing somatic growth, is largely influenced by rising temperature and increasing lengths of daylight (Craig 2000). Thus, the majority of somatic growth in yellow perch occurs during warmer, summer months. In Lake Monona, Wisconsin, yellow perch maintained thermal regulation by avoiding extreme water temperatures near a power plant outflow (Neill and 
Magnusson 1974). This evidence suggests that thermal regulation may be more important to physiological processes governing growth than prey availability and other biological factors (Neill and Magnusson 1974; Craig 2000). A preferred summer temperature has been described by Fergusson (1958) to be between 17.6 and $25.0^{\circ} \mathrm{C}$ with yellow perch following a $20^{\circ} \mathrm{C}$ isotherm, seasonally. Hokanson (1977) found the physiological optimal temperature for yellow perch to be $24.7^{\circ} \mathrm{C}$ and a critical thermal maximum at $33.4^{\circ} \mathrm{C}$.

Significant variability in growth rate exists between populations of yellow perch. This variability can be largely attributed to differences in both biotic and abiotic factors unique to different aquatic ecosystems. Ney (1978) suggests that variation in growth is the most noticeable within the first year of an individual's life. Size-related sexual dimorphism is also prevalent among yellow perch. Growth rates of male yellow perch are typically slower than females, and females tend to outlive their male counter-parts (Scott and Crossman 1973; Jenkins and Burkhead 1993; Brofka and Marsden 1993; Moyle 2002, Purchase et al. 2005). Latitudinal variability in growth rates has also been documented in yellow perch and closely related species. At southern latitudes, yellow perch generally grow much faster and achieve larger maximum sizes (Craig 2002; Brown et al. 2009). Similar trends were documented in European perch (Heibo et al. 2005) and walleye (Quist et al. 2003). Latitudinal variations in growth rate of percid species are likely related to extended growing periods, resulting from increased annual temperatures and extended day-lengths occurring in southern populations.

Negative correlations between growth rates and population density have also been documented by several authors, indicative of density-dependent stunting (Ney 1978; Heath and Roff 1987; McPhail 2007; Munro and MacMillan 2010). Density-dependent 
stunting of growth within populations is more common in smaller aquatic environments, such as small reservoirs and ponds. Owing to high recruitment rates, adaptability to various habitat types, and plasticity in foraging behaviors, yellow perch are often able to out-breed and out-compete other species in the aquatic community (McPhail 2007).

As a diurnal species, the yellow perch relies primarily on vision for feeding purposes (Ali et al. 1977). Thus, growth can be greatly reduced in populations inhabiting turbid waters. In eutrophic environments, increased light attenuation by suspended phytoplankton and algae can heavily impact visibility. Boisclair and Rassmussen (1996) suggested reduced growth in yellow perch inhabiting eutrophic waters. In general, growth rates can be affected by the quantity and quality of available prey. However, studies have shown that total abundance of all species within a fish community has a larger impact on growth in yellow perch than the quantities and types of prey consumed (Boisclair and Leggett 1989a, 1989b, 1989c; Boisclair and Rassmussen 1996). This suggests that growth in yellow perch is largely weighted toward interspecific competition, rather than dietary composition. Research conducted by Aubin-Horth et al. (1999) indicated higher rates of growth in less active populations where prey is readily available.

\section{Condition}

Various indices have been developed to evaluate the general health and well-being in populations of fishes. The relative weight index $\left(W_{r}=\frac{W}{W_{s}} \times 100\right)$, developed by Wege and Anderson (1978), is commonly used as a standardized method for evaluating condition (Anderson and Neumann 1996; Blackwell et al. 2000; Pope and Kruse 2007; Neumann et al. 2012); where $W$ is the weight of an individual fish, and $W_{s}$ is the lengthspecific standard weight. Calculation of $W_{r}$ is based largely on standard weight equations 
$\left(W_{s}\right)$, developed for interpopulational comparisons (Murphy et al 1991). Murphy et al.

(1990) used a technique for development of $W_{s}$ in walleye, based on $75^{\text {th }}$ percentile weights, that has become standard.

The standard weight equation for yellow perch (Willis et al. 1991) is applicable to individuals exceeding $100 \mathrm{~mm}$ TL:

$$
\log _{10} W_{s}=-5.386+\log _{10} L
$$

Willis et al. (1991) noted geographic variability in condition among populations, and suggested that higher $W_{r}$ occuring in mid-western states may be attributed to increased productivity resulting from agricultural run-off. Seasonal fluctutations in $W_{r}$ can occur, owing to variability in lipid storage and consumption rates occuring within fish populations. Guy and Willis (1991) and Hayes and Taylor (1994) suggested that $W_{r}$ values among yellow perch populations are maximized throughout the summer months, when growth rates are highest. Therefore, seasonal influences on condition must be considered when comparing $W_{r}$ values.

\section{Study Area}

Cheat Lake was formed in 1926 by the completion of efforts to construct a hydroelectric dam by the West Penn Power Company (Jernejcic and Wellman 2011). Construction began on the Lake Lynn Hydropower Project in 1914 and ended in 1926 with the completion of the Lake Lynn dam and hydropower station (Core 1959). The reservoir is located near the West Virginia/Pennsylvania border, roughly $12 \mathrm{~km}$ northeast of Morgantown, West Virginia. Cheat Lake is $21 \mathrm{~km}$ in length, and has a surface area of approximately 700 ha. 
Operations of the Lake Lynn hydroelectric dam are regulated by the Federal Energy Regulatory Commission (FERC). The operating license for the hydroelectric services expired in 1994, but was renewed for a 30-year period. Several new stipulations were included in the new contract, including a minimum flow rate of 212 cubic feet per second to mitigate poor water quality of the Cheat River downstream of Cheat Lake and to establish a tailwater fishery for recreational anglers (Jernejcic and Wellman 2011). In addition to downstream flow requirements, annual biomonitoring of the fish assemblage and specific regulations associated with seasonal water level fluctuation were also included in the operating agreement. Water level restrictions, reported as lake elevation (ft.) above sea level, are as follows: May-October (868-870 ft.), November-March (857$870 \mathrm{ft}$. ) and April (863-870 ft.). Jernejcic and Wellman (2011) stated that these restrictions were implemented to allow recreational use of the lake (May-October), maximize hydroelectric power generation from the dam (November-March), and to enhance recruitment by yellow perch and walleye during spring spawning events (April).

The upper reaches of the watershed have historically been impacted by poor water quality resulting from acid precipitation and acid mine drainage from abandoned mine sites (Welsh and Perry 1997), which in-turn impacts the Cheat River downstream. Thus, Cheat Lake has been negatively impacted by acidification since its establishment, and seasonal fluctuations in $\mathrm{pH}$ within the lake are still a common occurrence. As a result, biologists avoided management of Cheat Lake fisheries until the 1990's (Jernejcic and Wellman 2011).

Yellow perch and walleye were historically present within the Cheat River. However, yellow perch and walleye were thought to be extirpated from the drainage, with 
the last documented individuals being caught in the early 1940's (Core 1959). As a direct result of improving water conditions, there has been a recent resurgence of a selfsustaining yellow perch population within Cheat Lake. During annual biomonitoring of the fish assemblage, a notable trend in increasing size structure and population density of yellow perch was observed until 2005. Angler reports and limited data collected during annual biomonitoring indicated an abundance of large yellow perch in 2005 (Jernejcic and Wellman 2011). In 2007, a creel limit of 15 yellow perch per day was implemented to combat an ensuing increase in harvest rates of large individuals. Recently, anglers have reported substantial declines in the abundance of larger individuals, indicative of a changing size-structure within the Cheat Lake yellow perch population. Thus, fisheryindependent data are needed for management purposes.

In summary, the biology and ecology of yellow perch have been well documented by various authors. However, variability occurs between populations, owing to the extensive distribution of the species. Research conducted at finer geographic scales is essential to evaluating region-specific trends among populations of yellow perch, and limited information exists regarding populations occurring in West Virginia. This chapter on the ecology, life history, diet, and growth of yellow perch provides a literature review in support of my thesis research, and information regarding age, summer diet composition, and growth of yellow perch in Cheat Lake, West Virginia are provided in the following chapter. 


\section{Literature Cited}

Anderson, R. O., and R. M. Neumann. 1996. Length, weight, and associated structural indices. Pages 447-482 in B. R. Murphy and D. W. Willis, editors. Fisheries techniques, 2nd edition. American Fisheries Society, Bethesda, Maryland.

Aubin-Horth, N., J. Gingras, and D. Boisclair. 1999. Comparison of activity rates of 11 yellow perch (Perca flavescens) from populations of contrasting growth rates using underwater video observations. Canadian Journal of Fisheries and Aquatic Sciences 56:1122-1132.

Becker, G. 1983. Freshwater fishes of Wisconsin. University of Wisconsin Press, Madison, Wisconsin.

Blackwell, B. G., M. L. Brown, and D. W. Willis. 2000. Relative weight (Wr) status and current use in fisheries assessment and management. Reviews in Fisheries Science $8: 1-44$.

Boisclair, D., and W. C. Leggett. 1989a. Among population variability of fish growth, I. Influence of quantity of food consumed. Canadian Journal of Fisheries and Aquatic Sciences 46:457-467.

Boisclair, D., and W. C. Leggett. 1989b. Among population variability of fish growth, II. Influence of prey type. Canadian Journal of Fisheries and Aquatic Sciences 46:468-482.

Boisclair, D., and W. C. Leggett. 1989c. Among population variability of fish growth, III. Influence of fish community. Canadian Journal of Fisheries and Aquatic Sciences 46:1539-1550.

Boisclair, D., and J. B. Rasmussen. 1996. Empirical analysis of the influence of environmental variables associated with lake eutrophication on perch growth, consumption, and activity rates. Annales Zoologici Fennici 33:507-515.

Brazo, D., P. Tack, and C. Liston. 1975. Age, growth, and fecundity of yellow perch, Perca flavescens, in Lake Michigan near Ludington, Michigan. Transactions of the American Fisheries Society 104:726-730.

Brofka, W. A., and J. Marsden. 1993. A survey of sport fishing in the Illinois portion of Lake Michigan. Annual Report to the Illinois Department of Conservation, Aquatic Ecology Technical Report 93/4, Champaign. 
Brown, C., and J. E. Bailey. 1952. Time and pattern of scale formation in yellowstone cutthroat trout (Salmo clarkii lewisii). Transactions of the American Microscopial Society 71:120-124.

Brown, T., B. Runciman, M. Bradford, and S. Pollard. 2009. A biological synopsis of yellow perch (Perca flavescens). Canadian Manuscript Report of Fisheries and Aquatic Sciences 2883: v-28.

Carney, J., and T. Dick. 1999. Enteric helminths of perch (Perca fluviatilis L.) and yellow perch (Perca flavescens Mitchill): Stochastic or predictable assemblages? The Journal of Parasitology 85:785-795.

Clady, M., and B. Hutchison. 1975. Effect of high winds on eggs of yellow perch, Perca flavescens, in Oneida Lake, New York. Transactions of the American Fisheries Society 104:524-525.

Collette, B. B., and P. Banarescu. 1977. Systematics and zoogeography of the fishes of the family Percidae. Journal of the Fisheries Research Board of Canada 34:1450-1463.

Core, E. L. 1959. Biological investigations of Cheat Lake: Summary. West Virginia University, Morgantown, West Virginia

Craig, J. F. 2000. Percid fishes: systematics, ecology and exploitation. Blackwell Science, Oxford.

Creque, S. M., and S. J. Czesny. 2012. Diet overlap of non-native alewife with native yellow perch and spottail shiner in nearshore waters of southwestern Lake Michigan, 2000-2007. Ecology of Freshwater Fish 21:207-221.

Echo, J. 1955. Some ecological relationships between yellow perch and trout in Thompson Lake, Montana. Transactions of the American Fisheries Society 84:239-248.

Eggers, D. M., N. W. Bartoo, N. A. Rickard, R. E. Nelson, R. C. Wissmar, R. L. Burgner, and A. H. Devol. 1978. The Lake Washington ecosystem: The perspective from the fish community production and forage base. Journal of Fisheries Research Board of Canada 35:1553-1571.

Everhart, H. W. 1949. Body length of the smallmouth bass at scale formation. Copeia 1949:110-115.

Ferguson, R. 1958. The preferred temperatures of fish and their midsummer distribution in temperate lakes and streams. Journal of the Fisheries Research Board of Canada 15:607-624. 
Fisher, S. J., M. R. Anderson, and D. W. Willis. 1998. Total length reduction in preserved yellow perch larvae. North American Journal of Fisheries Management 18:739742.

Fullhart, H. G., B. G. Parsons, D. W. Willis, and J. R. Reed. 2002. Yellow perch piscivory and its possible role in structuring littoral zone fish communities in small Minnesota lakes. Journal of Freshwater Ecology 17:37-43.

Garvey, J. E., and S. R. Chipps. 2012. Diets and energy flow. Pages 733-779 in A. V. Zale, D. L. Parrish, and T. M. Sutton, editors. Fisheries techniques, 3rd edition. American Fisheries Society, Bethesda, Maryland.

Guy, C. S., and D. W. Willis. 1991. Evaluation of largemouth bass-yellow perch communities in small South Dakota impoundments. North American Journal of Fisheries Management 11:43-49.

Hardy, J. D., Jr. 1978. Development of fishes of the mid-Atlantic Bight. Volume III. U.S. Fish and Wildlife Service. Department of the Interior, Washington, D.C.

Harrington, R. W., Jr. 1947. Observations on the breeding habits of the yellow perch, Perca flavescens (Mitchill). Copeia 1947:199-200.

Hasler, A. D., and J. E. Bardach. 1949. Daily migrations of perch in Lake Mendota, Wisconsin. Journal of Wildlife Management 13:40-51

Hasler, A. D. and J. R. Villemonte. 1953. Observations on the daily movement of fishes. Science 118:321-322.

Hasler, A. D., and G. L. Hergenrader. 1968. Influence of changing season on schooling behavior of yellow perch. Journal of Fisheries Research Board of Canada 25:711716.

Hayes, D. B, and W. W. Taylor. 1994. Changes in the composition of somatic and gonadal tissues of yellow perch following white sucker removal. Transactions of the American Fisheries Society 123:204-216.

Heath, D., and D. A. Roff. 1987. Test of genetic differentiation in growth of stunted and nonstunted populations of yellow perch and pumpkinseed. Transactions of the American Fisheries Society 116:98-102.

Heath, D. D., and D. A. Roff. 1995. The role of trophic bottlenecks in stunting: A field test of an allocation model of growth and reproduction in yellow perch, Perca flavescens. Evironmental Biology of Fishes, 45:53-63. 
Heibo, E., C. Magnhagen, and L. A. Vøllestad. 2005. Latitudinal variation in life-history traits in Eurasian perch. Ecology 86:3377-3386.

Helfman, G. S. 1979. Twilight activities of yellow perch (Perca flavescens). Journal of the Fisheries Research Board of Canada 36:173-179.

Herman, E., W. Wisbey, L. Wiegert, and M. Burdick. 1959. The yellow perch: Its life history, ecology, and management. Wisconsin Conservation Department Publication 228. Madison, Wisconsin.

Hinshaw, J. M. 1985. Effects of illumination and prey contrast on survival and growth of larval yellow perch, Perca flavescens, Transactions of the American Fisheries Society 114:540-545.

Hokanson, K. E. F. 1977. Temperature requirements of some percids and adaptations to the seasonal temperature cycle. Journal of the Fisheries Research Board of Canada 34:1524-1550.

Holland-Bartels, L. E., S. K. Littlejohn and M. L. Huston. 1990. A guide to larval fishes of the upper Mississippi River. US Fish and Wildlife Service, LaCrosse, Wisconsin.

Hubert, W. A., and M. B. Sandheinrich. 1983. Patterns of variation in gill-net catch and diet of yellow perch in a stratified Iowa lake. North American Journal of Fisheries Management 3:156-162.

Jenkins, R. E., and N. M. Burkhead. 1993. Freshwater Fishes of Virginia. American Fisheries Society, Bethesda, Maryland.

Jernejcic, F., and D. Wellman. 2011. The recovery of Cheat Lake (a success story). West Virginia Wildlife 1:2-6.

Jobes, F. W. 1952. Age, growth, and production of yellow perch in Lake Erie. U.S. Fish and Wildlife Service Bulletin 52:205-266.

Joblin, M. 1995. Environmental biology of fishes. Chapman and Hall, London.

Keast, A. 1977. Diet overlap and feeding relationships between the year classes in the yellow perch Perca flavescens. Environmental Biology of Fishes 2:53-70.

Keast, A. 1985. The piscivore feeding guild of the fishes in small freshwater ecosystems. Environmental Biology of Fishes 12:119-129. 
Knight, R. L., J. F. Margraf, and R. F. Carline. 1984. Piscivory by walleyes and yellow perch in western Lake Erie. Transactions of the American Fisheries Society 113:677-693.

Lott, J. P., D. W. Willis, and D. O. Lucchesi. 1996. Relationship of food habits to yellow perch growth and population structure in South Dakota lakes. Journal of Freshwater Ecology 11:27-37.

Mansueti, A. J. 1964. Early development of the yellow perch, Perca flavescens. Chesapeake Science 5:46-66.

McPhail, J. D. 2007. Freshwater fishes of British Columbia. University of Alberta Press, Edmonton.

McPhail, J. D., and C. C. Lindsay. 1970. Freshwater fishes of northwestern Canada and Alaska. Bulletin of the Fisheries Research Board of Canada 173:1-373.

Moyle, P. B. 2002. Inland fishes of California. University of California Press, Berkley.

Muncy, R. J. 1962. Life history of the yellow perch, Perca flavescens, in estuarine waters of Severn River, a tributary of Chesapeake Bay, Maryland. Chesapeake Science 3:143-159.

Munro, C. L., and J. L. MacMillan. 2010. Overpopulation and growth of yellow perch (Perca flavescens) and the potential effect of increased competition on brook trout (Salvelinus fontinalis) in Long Lake, Halifax County, Nova Scotia. Department of Fisheries and Aquaculture: Inland Fisheries Division, Report B0K 1H0, Pictou, Nova Scotia.

Murphy, B. R., M. L. Brown, and T. A. Springer. 1990. Evaluation of the relative weight (Wr) index, with new application to walleye. North American Journal of Fisheries Management 10:85-97.

Murphy, B. R., D. W. Willis, and T. A. Spring. 1991. The relative weight index in fisheries management: status and needs. Fisheries 16:30-38.

Nelson, W. R., and C. H. Walburg. 1977. Population dynamics of yellow perch (Perca flavescens), sauger (Stizostedion canadense), and walleye (S. vitreum vitreum) in four main stem Missouri River reservoirs. Journal of the Fisheries Research Board of Canada 34:1748-1763.

Neill, W. H., and J. J. Magnuson. 1974. Distributional ecology and behavioral thermoregulation of fishes in relation to heated effluent from a power plant at Lake Monona. Wisconsin. Transactions of the American Fisheries Society 103:663-710. 
Neumann, R. M., C. G. Guy, and D. W. Willis. 2012. Length, weight, and associated indices. Pages 637-676 in A. V. Zale, D. L. Parrish, and T. M. Sutton, editors. Fisheries techniques, 3rd edition. American Fisheries Society, Bethesda

Newsome, G. E., and J. Tompkins. 1985. Yellow perch egg masses deter predators. Canadian Journal of Zoology 63:2882-2884.

Ney, J. J. 1978. A synoptic review of yellow perch and walleye biology. American Fisheries Society Special Publication 11:1-12.

Ney, J. J., and L. L. Smith, Jr. 1975. First-year growth of the yellow perch, Perca flavescens, in the Red Lakes, Minnesota. Transactions of the American Fisheries Society 104:718-725.

Noble, R. L. 1970. Evaluation of the miller high-speed sampler for sampling yellow perch and walleye fry. Journal of the Fisheries Research Board of Canada 27:1033-1044.

Noble R. L. 1975. Growth of young yellow perch (Perca flavescens) in relation to zooplankton populations. Transactions of the American Fisheries Society 104:731741.

Parker, J. B. 1942. Some observations on the reproductive system of the yellow perch (Perca flavescens). Copeia 1942:223-226.

Parsons, J. W. 1950. Growth studies of yellow perch, Perca flavescens (Mitchill), in three northwest Iowa lakes. Iowa State College Journal of Science 25:495-500.

Paukert, C. P., and D. W. Willis. 2001. Comparison of exploited and unexploited yellow perch Perca flavescens (Mitchill) populations in Nebraska Sandhill lakes. Fisheries Management and Ecology 8:533-542.

Paxton, K. O., and F. Stevenson. 1978. Food, growth, and exploitation of percids in Ohio upground reservoirs. American Fisheries Society Special Publication 11:270-277.

Purchase, C. F., N. C. Collins, G. E. Morgan, and B. J. Shuter. 2005. Predicting life history traits of yellow perch from environmental characteristics of lakes. Transactions of the American Fisheries Society 134:1369-1381.

Pycha, R. L., and L. L. Smith, Jr. 1955. Early life history of the yellow perch in the Red Lakes, Minnesota. Transactions of the American Fisheries Society 84:249-260.

Quist M. C., C. S. Guy, R. D. Schultz, and J. L. Stephen. 2003. Latitudinal comparison of walleye growth in North America and factors influencing growth of walleyes in Kansas reservoirs. North American Journal of Fisheries Management 23:677-692. 
Regier, H. A., V. C. Applegate and R. A. Ryder. 1969. The ecology and management of the walleye in western Lake Erie. Great Lakes Fisheries Commission Technical Report 15, Ann Arbor, Michigan.

Roberge, M., T. Slaney, and C. Minns. 2001. Life history characteristics of freshwater fishes occurring in British Columbia, with major emphasis on lake habitat characteristics. Canadian Manuscript Report of Fisheries and Aquatic Sciences 2574.

Robillard, S. R., and E. J. Marsden. 2007. Spawning substrate preferences of yellow perch along a sand-cobble shoreline in southwestern Lake Michigan. North American Journal of Fisheries Management 21:208-215.

Sandheinrich, M. B., and W. A. Hubert. 1984. Intraspecific resource partitioning by yellow perch in a stratified lake. Canadian Journal of Fisheries and Aquatic Sciences 41:1745-1752.

Scott, D. C. 1955. Activity patterns of perch. Ecology 36:320-327.

Scott, W. B., and E. J. Crossman. 1973. Freshwater fishes of Canada. Journal of the Fisheries Research Board of Canada Bulletin 184.

Seaburg, K. G., and J. B. Moyle. 1964. Feeding habits, digestion rates, and growth of some Minnesota warmwater fishes. Transactions of the American Fisheries Society 93:269-285.

Smith, C. L. 1986. Inland fishes of New York State. New York Department of Environmental Conservation, Albany.

Swindoll, C. M. 1981. The growth, diet, and distribution of yellow perch fry in Lake Itasca, Minnesota. Masters thesis. University of Tennessee, Knoxville.

Tarby, M. J. 1974. Characteristics of yellow perch cannibalism in Oneida Lake and the relation to first year survival. Transactions of the American Fisheries Society 103:462-471.

Thorpe, J. E. 1977. Morphology, physiology, behavior, and ecology of Perca fluviatilis L. and P. flavescens Mitchill. Journal of the Fisheries Research Board of Canada 34:1504-1514.

Tsai, C. F., and G. R. Gibson. 1971. Fecundity of the yellow perch, Perca flavescens Mitchill, in the Patuxent River, Maryland. Chesapeake Science 12:270-284.

Weber, M. J., J. M. Dettmers, and D. H. Wahl. 2011. Growth and survival of age-0 yellow perch across habitats in southwestern Lake Michigan: Early life history in a large 
freshwater environment. Transactions of the American Fisheries Society 140:11721185.

Wege, G. J., and R. O. Anderson. 1978 . Relative weight (Wr) : a new index of condition for largemouth bass. Pages 79-91 in G. D. Novinger and J . G. Dillard, editors . New approaches to the management of small impoundments. American Fisheries Society, North Central Division, Special Publication 5, Bethesda, Maryland.

Weisberg, S. B., and A. J. Janicki. 1990. Summer feeding patterns of white perch, channel catfish, and yellow perch in the Susquehanna River, Maryland. Journal of Freshwater Ecology 5:391-405.

Wells, L., and S. C. Jorgenson. 1983. Population biology of yellow perch in southern Lake Michigan, 1971-1979. U.S. Fish and Wildlife Services Technical Paper 113.

Welsh, S. A., and S. A. Perry. 1997. Acidification and fish occurrence in the upper Cheat River drainage, West Virginia. Journal of the American Water Resources Association 33:432-429.

Whiteside, M. C., C. M. Swindoll, and W. L. Doolittle. 1985. Factors affecting the early life history of yellow perch, Perca flavescens. Environmental Biology of Fish 12:47-56.

Willis, D. W., C. S. Guy, and B. R. Murphy. 1991. Development and evaluation of a standard weight $(W s)$ equation for yellow perch. North American Journal of Fisheries Management 11:374-380. 


\title{
CHAPTER 2: Assessment of Age, Diet, and Growth of Yellow Perch in Cheat Lake, West Virginia
}

\author{
Abstract \\ Assessment of Age, Diet, and Growth of Yellow Perch (Perca flavescens) in \\ Cheat Lake, West Virginia
}

Nate Taylor

Water quality in Cheat Lake (700 ha reservoir on Cheat River in Monongalia County, West Virginia) has been significantly influenced by acid mine drainage since its formation in 1926. Recent mitigation efforts of upstream waters have resulted in improved water quality and increases in population size of several fish species in the reservoir, including yellow perch (Perca flavescens). Currently, Cheat Lake is one of the few reservoirs in West Virginia supporting a yellow perch fishery, and fishery-

independent data on this unique population are needed for management. For this study, I evaluated age and length, summer diet composition, and growth for Cheat Lake yellow perch, providing useful information for management of the fishery. The sample $(n=271)$ included individuals of a wide range of ages (0-9) and sizes $(66-320 \mathrm{~mm})$. Genderspecific differences in growth rate were observed beginning at Age-2. Females grew faster and attained larger maximum sizes than males. An information theoretic approach was taken to evaluate the applicability of various growth models. Four candidate models (von Bertalanffy, Gompertz, logistic, and power) were fitted to mean length-at-age data. The von Bertalanffy growth model was selected by AICc as the best approximating model, and data also provided some evidence supporting the Gompertz model. A combination of quantitative methods and multivariate statistics were used to evaluate differences in summer diet composition among Age-0, Age-1, and Age-2+ individuals. Ontogenetic diet shifts were observed. Zooplankton (primarily Copepods) was identified from all Age-0 individuals. Trichoptera and Chironomidae were the most important prey items for Age-1 yellow perch. Fishes were identified among the stomach contents from $41.5 \%$ of all Age-2+ individuals. Cheat Lake is one of a few reservoirs in West Virginia that supports a yellow perch fishery, and fishery-independent data from this study represent the first comprehensive assessment of this fishery. Baseline data for management and future stock assessments were provided by this investigation. 


\section{Introduction}

The yellow perch, Perca flavescens, is an economically-important natural resource, targeted for both recreational and commercial fishing purposes throughout much of its broad distribution in North America. As a result, extensive literature exists relative to various aspects of the biology and ecology of yellow perch. However, due to the broad distribution of yellow perch, geographic variability among populations requires regionspecific research to fill information gaps present within the literature. Limited information exists regarding yellow perch populations occurring in West Virginia and much of the surrounding region.

Yellow perch populations differ in age and length structure, diet, and growth rates. Population characteristics can be influenced by both biotic and abiotic conditions, undoubtedly differing both temporally and spatially among aquatic systems. Differences in growth rates between populations of yellow perch have been attributed to several factors: increased intra-specific competition related to population density (Ney 1978; Heath and Roff 1987; McPhail 2007; Munro and MacMillan 2010), inter-specific competition with other fish species (Hanson and Leggett 1986; Boisclair and Leggett 1989a, 1989b, 1989c; Boisclair and Rassmussen 1996; Fullhart et al. 2002; Schoenbeck and Brown 2009), and quality of prey present in the diet (Lott et al. 1996; Fullhart et al. 2002). Authors have suggested trends along a latitudinal gradient to influence age structure, maturation rates, and growth rates in yellow perch (Craig 2000; Brown et al. 2009). A similar pattern was described in both P. fluviatilis (Heibo et al. 2005) and Sander vitreus (Quist et al. 2003), in which longevity was maximized in northern populations and increased rates of growth and maturation occurred in southern 
populations. Latitudinal variation between populations likely results from higher annual temperatures and extended growing seasons at southern latitudes. Thus, fisheryindependent data are often essential to management of regional yellow perch fisheries.

Cheat Lake supports one of the most productive yellow perch fisheries within West Virginia, and current management of this unique population has been based on limited information. In 2005, yellow perch exceeding $300 \mathrm{~mm}$ TL were abundant in Cheat Lake, and the recreational angling community began to acknowledge the potential for harvesting large individuals. Recognizing the possibility of an ensuing increase in angler effort, managers implemented a daily creel limit of 15 individuals in 2007 to ensure the future of this unique fishery. Currently, limited information exists regarding this valuable yellow perch population, and fishery-independent data are needed for management purposes. Thus, the primary objective of this study was to obtain information which could be incorporated into future management decisions. Thus, size structure, age structure, mortality, condition, and growth were evaluated.

Authors (Robillard and Mardsen 1996; Niewinski and Ferrerri 1999; Lucchesi and Johnson 2006) have suggested otoliths as the most accurate structure for age determination in yellow perch. Unfortunately, individuals must be sacrificed for otolith removal. However, additional information can be collected from internal examination of sacrificed individuals that cannot be attained from external observations. Gonadal inspection allows for accurate sex determination, and provides supplemental data for exploring gender-related variability in growth, survivorship, resource use, etc. Information regarding foraging habits can provide valuable insight into biotic factors contributing to growth rates and overall health of a population. Thus, prey items found in 
the stomachs of sacrificed individuals were used to evaluate the summer diet of Cheat Lake yellow perch.

\section{Methods}

\section{Study Area}

Cheat Lake is a 700 ha reservoir located in Monongalia County, West Virginia. Established in 1926 for hydropower generation purposes, the impoundment is $21-\mathrm{km}$ in length, and a maximum depth of approximately $25 \mathrm{~m}$ is located near the dam. The reservoir is also dimictic, experiencing seasonal stratification. Since its establishment, water quality in Cheat Lake has been influenced by acid precipitation (Welsh and Perry 1997) and run-off from abandoned mining practices (Freund and Petty 2007; Merovich et al. 2007) occurring throughout much of the Cheat River watershed since its establishment. Mitigation efforts within the upper Cheat River watershed (McClurg et al. 2007) may have contributed to recent improvements in water quality in Cheat Lake. Currently, Cheat Lake supports a diverse assemblage of sport fishes, consisting largely of channel catfish (Ictalurus punctatus), white bass (Morone chrysops), black crappies (Pomoxis nigromaculatus), smallmouth bass (Micropterus dolomieu), spotted bass (Micropterus punctulatus), largemouth bass (Micropterus salmoides), bluegills (Lepomis macrochirus), pumpkinseeds (Lepomis gibbosus), walleye (Sander vitreus), and yellow perch (Perca flavescens).

\section{Collection}

Owing to thermal requirements, passive collecting methods are often used to sample yellow perch from deeper waters during warmer summer months, such as gill nets (Paxton et al. 1978; Sandheinrich and Hubert 1984; McCarty 1990; Kraft and Johnson 
1992; Lott et al. 1996) and fyke nets (Kraft and Johnson 1992; Parker et al. 2009).

However, schools of yellow perch disperse after dark, and individuals remain inactive in shallow waters throughout much of the night (Hasler and Villemonte 1953; Scott 1955; Craig 2000). Because of this diel behavior, yellow perch were sampled after dusk using a boat-mounted Smith-Root electrofisher for this study. A total of 271 yellow perch were collected on six dates between 9 July and 4 September 2012.

\section{Evaluation of Sex, Size Structure, Age Structure, Mortality, and Condition}

Length and weight data are essential to fisheries science and management as they provide valuable information regarding the size structure within a population. In the presence of complementary age data, measurements of length and weight are also fundamental for estimating growth. Because previous research has suggested length and weight measurements of yellow perch can be influenced by both preservation (Stobo 1972; Engel 1974; Johnson and Swanson 1974) and freezing (Engel 1974), length and weight of individuals were determined at time of collection. Total length (TL) of each individual was measured to the nearest millimeter $(\mathrm{mm})$ and weight was determined to the nearest gram (g) using a digital scale (Ohaus ${ }^{\circledR}$ Valor 2000 Series - Model V21PW6). The relationship between length and weight was evaluated using the power function: $W=a L^{b}$, where $W$ is weight, $L$ is length, and $a$ and $b$ are parameters of the model. The Fisheries Analysis and Modeling Simulator (FAMS 1.0; Slipke and Maceina 2010) was used to solve for parameter estimates using linear regression and the logarithmic transformation of the Power model: $\log _{10} W=a^{\prime}+b \log _{10} L$.

Malison et al. (2011) described methods to identify sex of individuals based on external features. However, apart from morphological differences present during 
spawning period, sex determination among Perca species is difficult from external appearances. During summer, yellow perch are in a post-spawning state and energetic gains are focused primarily on somatic growth. Thus, sexual differentiation based solely on external morphology proved to be an invalid method for sex determination in this study. Sex was accurately determined through gonadal inspection in the laboratory.

A length-frequency histogram of size distributions among the 271 individuals included in the sample was used to evaluate size structure of the Cheat Lake yellow perch population. In comparison to many other game fishes, the maximum sizes attained by yellow perch are relatively small, and length-frequency distributions were evaluated at 1$\mathrm{cm}$ size intervals to best represent population-based trends present among the data (Miranda 2007; Neumann et al. 2007, 2012). Sexual size dimorphism occurs in yellow perch, with females typically growing faster and achieving larger maximum sizes than males (Jenkins and Burkhead 1993; Brofka and Marsden 1993; Purchase et al. 2005). To evaluate gender-specific influences on population size structure, sex was incorporated into the length-frequency histogram.

Proportional size distribution $\left(\mathrm{PSD}_{x}=\frac{\text { Number of fish } \geq \text { specified length }}{\text { Number of fish } \geq \text { stock length }}\right)$ indices (Anderson, 1976; Wege and Anderson, 1978; Guy et al. 2007) are commonly used as numerical descriptors of length-frequency data (Neumann et al. 2007, 2012). The Gabelhouse (1984) five-cell length classification system for yellow perch was used for calculation of traditional $\mathrm{PSD}_{x}$ indices for a numerical representation of size structure for Cheat Lake yellow perch a complementary measure to length-frequency distributions: 
stock $(\geq 130 \mathrm{~mm})$, quality $(\geq 200 \mathrm{~mm})$, preferred $(\geq 250 \mathrm{~mm})$, memorable $(\geq 300 \mathrm{~mm})$, and trophy $(\geq 380 \mathrm{~mm})$.

Although multiple structures have been used for age determination (Devries and Frie 1996; Quist et al. 2012), studies have suggested that sagittal otoliths provide the most accurate estimations of age for yellow perch (Robillard and Marsden 1996; Niewinski and Ferreri 1999; Lucchesi and Johnson 2006). Otoliths were extracted in the laboratory, and viewed (whole) through the ventral surface. Black, oil-based modeling clay provided a contrasting background for visual inspection of annuli. Although submersion oil is often used to improve visual clarity for viewing otoliths, water proved to be a sufficient alternative in this study. Two readers independently aged individuals to promote consistency among age data. Because annulus formation typically occurs later in larger yellow perch (Blackwell and Kaufman 2012), distance between otolith annuli was considered during age determination. Age structure was evaluated using a histogram of age-frequency distributions among the sample.

Mortality describes the extent to which individuals are lost from a population, a central component to understanding population dynamics and management of fisheries (Miranda and Bettolli 2007) The Fisheries Analysis and Modeling Simulator (FAMS 1.0; Slipke and Maceina 2010) was used to calculated instantaneous mortality rate $(Z)$ and percent annual survival $(S)$ by catch-curve analysis. Weighted linear regression was used to fit a weighted catch-curve to number-at-age data from the sample, reducing the effect of fewer individuals incorporated among older year-classes in the sample (Maceina 1997; Miranda and Bettolli 2007; Allen and Hightower 2010; Slipke and Maceina 2010). Analysis of number-at-age data predicted full recruitment to sampling gear among Age-2 
individuals. Thus, a total of 183 individuals ranging from Age-2 to Age-9 were included in catch-curve analysis. Assumptions of catch-curves are as follows: consistent annual recruitment rates, equal survival among year classes, constant annual survival rate, constant natural mortality and fishing mortality, and accurate representation of population age structure by the sample.

The relative weight index $\left(W_{r}=\frac{W}{W_{S}} \times 100\right)$ was used to evaluate the condition (Wege and Anderson 1978; Anderson and Neumann 1996; Pope and Kruse 2007; Neumann et al. 2012); where $W$ is the weight of an individual fish, and $W_{s}$ is the lengthspecific standard weight. The standard weight equation for yellow perch was developed by Willis et al. (1991), and is applicable to yellow perch exceeding $100 \mathrm{~mm}$ TL:

$$
\log _{10} W_{s}=-5.386+3.230 \log _{10} L
$$

Variability in lipid storage and consumption rates of yellow perch can occur seasonally within populations, resulting in seasonal fluctutations in $W_{r}$. Guy and Willis (1991) and Hayes and Taylor (1994) suggested that $W_{r}$ values of yellow perch populations are maximized during summer months, when growth rates are highest. Therefore, seasonal influences on condition must be considered when comparing $W_{r}$ values between populations or between samples collected from the same population over multiple years. Murphy et al. (1991) noted that evaluating $W_{r}$ among all size classes in a sample can mask population trends in condition relative to size. Thus, $W_{r}$ was determined for stock, quality, preferred, and memorable length individuals (Gabelhouse 1984).

\section{Growth Modeling}


The von Bertalanffy growth model is frequently accepted a-priori in studies evaluating growth in fishes. Although parameter estimates from the von Bertalanffy growth model are commonly reported among the fisheries literature, several authors have questioned the universal applicability of the model (Parker and Larkin 1959; Paloheimo and Dickie 1965; Ursin 1967; Roff 1980; Schnute 1981). Model-based biases can occur when using only the von Bertalanffy model, providing an inaccurate representation of growth (Patterson et al. 2001; Schnute and Richards 2001; Lin and Tzeng 2009). As an alternative, some authors have suggested using an information theoretic approach to minimize uncertainties associated with the use of a single model when evaluating growth of fishes (Katsanevakis 2006; Katsanevakis and Maravelias 2008; Lin and Tzeng 2009).

Akaike's Information Criterion (AIC) was used to select the best model representing mean length-at-age data collected from 271 yellow perch in Cheat Lake. Four candidate models $g_{i}(i=1-4)$ were fit to the data: von Bertalanffy growth model, Gompertz model, logistic model and power model. The von Bertalanffy growth model (von Bertalanffy 1938) assumes a linear decrease in growth rate with age. Both the Gompertz model (Gompertz 1825) and logistic model (Ricker 1975) are sigmoidal, assuming an exponential reduction in growth rate with age. Unlike the Gompertz model, the logistic model is symmetrical around a point of inflection. The power model differs from the other models in that it does not assume an asymptotic length. Equations representing each of the four candidate models are as follows:

$$
\begin{aligned}
& \text { von Bertalanffy model: } L(t)=L_{\infty}\left[1-e^{-k\left(t-t_{0}\right)}\right] \\
& \text { Gompertz model: } L(t)=L_{\infty} \exp \left[-e^{-k\left(t-t_{0}\right)}\right] \\
& \text { logistic model: } L(t)=L_{\infty}\left[1+e^{-k\left(t-t_{0}\right)}\right]^{-1}
\end{aligned}
$$


power model: $L(t)=b_{0}+b_{1} t^{B_{2}}$

In each of the four models, $L(t)$ represents length at a given age $(t)$. Parameters estimated for the von Bertalanffy, Gompertz, and logistic model were asymptotic length $\left(L_{\infty}\right)$, a unique growth parameter for the each of the models $(k)$, and the theoretical age at which length is equal to zero $\left(t_{0}\right)$.

An iterative process was used to fit the four candidate models using the GaussNewton algorithm incorporated in the non-linear least squares (nls) package in R. Akaike's Information Criterion (AIC) was used to select the candidate model with the most parsimonious fit (Akaike 1973). To account for possible biases associated with small sample size, the 'AICcmodavg' package for R was used to apply the bias-corrected form of Akaike's Information Criterion $\left(\mathrm{AIC}_{\mathrm{c}}\right)$ for model selection (Hurvich and Tsai 1989; Burnham and Anderson 2002). The equations used in calculating $\mathrm{AIC}_{\mathrm{c}}$ are as follows:

$$
\begin{gathered}
\mathrm{AIC}=n\left(\log \left(2 \pi \frac{R S S}{n}\right)+1\right)+2 k \\
\mathrm{AIC}_{\mathrm{c}}=\mathrm{AIC}+\frac{2 k(k+1)}{n-k-1}
\end{gathered}
$$

$R S S$ is the residual sum-of-squares from the fitted model, $n$ in the number of observations in the sample, and $k$ in the number of estimated parameters in the model. The model that returns the smallest $\mathrm{AIC}_{\mathrm{c}}$ score $\left(\mathrm{AIC}_{\mathrm{c}}, \min \right)$ is considered to be the best approximating model. $\mathrm{AIC}_{\mathrm{c}}$ scores for each of the candidate models are compared to $\mathrm{AIC}_{\mathrm{c}, \min }$ to get the distance $\left(\Delta_{\mathrm{i}}\right)$. Burnham and Anderson (2002) suggest that models with $\Delta_{\mathrm{i}}<2$ generally are supported by the data and should be considered, whereas there is little evidence supporting 
models with $\Delta_{\mathrm{i}}>10$. Akaike weights $\left(w_{i}\right)$ were calculated for each of the four candidate models:

$$
w_{i}=\frac{\exp \left(-0.5 \Delta_{i}\right)}{\sum_{k=1}^{4}\left(-0.5 \Delta_{k}\right)}
$$

Akaike weights $\left(w_{\mathrm{i}}\right)$ were considered in conjunction with $\mathrm{AIC}_{\mathrm{c}}$ scores as measures for model selection between the four candidate models.

\section{Comparative Analysis of Growth Rates}

The von Bertalanffy growth model is the most commonly used model for growth estimation, providing a "standardized" method for comparing growth rates between populations. Jackson et al. (2008) used the von Bertalanffy growth model to develop a standard length equation $\left(L_{\mathrm{s}}\right)$ for yellow perch:

$$
L_{s}=280.5\left[1-e^{-0.332(\text { age }+0.031)}\right]
$$

Similar to weight analyses for assessment of condition, data spanning the entire geographic distribution of yellow perch in North America were incorporated into the standard length model. A relative growth index was derived from the model as a comparative method for evaluating growth among populations. The standard length equation was plotted against a constrained von Bertalanffy growth model fitted to mean length-at-age data. The parameter estimate for $\mathrm{t}_{0}$ from the standard length equation (0.031) was defined when fitting the von Bertalanffy model to Cheat Lake data to improve graphical interpretation.

\section{Compositional Diet Analysis}

At time of collection, individuals were immediately placed on ice to prevent regurgitation and reduce further digestion of stomach contents (Doxtater 1963; Bowen 
1996; Lott et al. 1996; Chipps and Garvey 2007; Garvey and Chipps 2012). Yellow perch were dissected in the laboratory, and whole stomachs were extracted and placed in a $10 \%$ formalin solution. A minimum of two days was allotted for fixation of tissues. After several changes of water, stomachs were transferred to a $70 \%$ ethanol solution for preservation. Dietary components were identified to lowest possible taxonomic level, largely dependent on the degree of mastication and digestion (Peckarsky 1990; Smith 2001; Jessup et al. 2003; Merritt et al. 2008; Page and Burr 2011). Individuals with empty stomachs and individuals containing unidentifiable prey items were excluded from diet analyses.

Yellow perch are often described as dietary generalists, consuming a wide array of prey types. However, gape limitation plays a critical role in structuring the composition of diet among younger individuals. Thus, ontogenetic diet shifts occur as the physical restrictions preventing the consumption of larger prey items are alleviated. To evaluate variability in prey types utilized by yellow perch, individuals were placed into three age categories for diet analysis: Age-0, Age-1, and Age-2 ${ }^{+}$.

Three quantitative methods were used to describe the summer foraging habits among the three age categories for Cheat Lake yellow perch: percent frequency of occurrence $\left(O_{i}\right)$, mean percent composition by number $\left(M N_{i}\right)$, and prey-specific abundance $\left(P_{i}\right)$. Presence/absence data of various prey items were used to calculate percent frequency of occurrence $\left(O_{i}=\frac{J_{i}}{P} \times 100 \%\right)$; where $J_{i}$ is the number of fish containing a specific prey type $(i)$, and $P$ is the total number of fish in the sample which had food in their stomachs. Although frequency of occurrence provides no measure of energetic gain, 
it can be useful in describing homogeneity in diet composition at the population level (Bowen 1996; Chipps and Garvey 2007; Garvey and Chipps 2012).

Prey abundances were used to calculate mean percent composition by number $\left(M N_{i}=\frac{1}{P} \sum_{j=1}^{P}\left(\frac{N_{i j}}{\sum_{i=1}^{Q} N_{i j}}\right) \times 100 \%\right)$ for various prey types identified from individuals in each of the three age groups; where $J_{i}$ is the number of fish containing a specific prey type $(i), N_{i j}$ is the quantity of prey type $i$ in each fish $(j), P$ is the number of fish that had prey in their stomachs, and $Q$ is the number of different prey items included in the dataset. Unlike frequency of occurrence, percent composition by number is calculated for individual fish (Bowen 1996). Because smaller prey items will likely occur in greater quantities than larger prey, percent composition by number is often considered to be ineffective for evaluating the contributions of various prey types to the overall diet (Bowen 1996). For this reason, percent composition by number is often reported as complementary data to percent composition by weight. Due to varying rates at which prey types are digested and uncertainty in the time of consumption, percent composition by weight was not calculated for this study.

Prey-specific abundance $\left(P_{i}=\frac{\sum s_{i}}{\Sigma s_{t i}} \times 100 \%\right)$ is defined as the proportion a specific prey type comprises of all prey items incorporated in the stomach contents of predators that that have consumed the specified prey; where $P_{i}$ is the prey-specific abundance of prey type $i, S_{i}$ is the proportion of total stomach contents comprised by prey $i$, and $S_{t i}$ is the total number of all prey items in the diet of all predators that have consumed prey type $i$ (Amundson 1996). As with frequency of occurrence, prey-specific abundance is measure that was pooled across all individuals in each of the three age 
groups. Although prey-specific abundance provides similar information to percent composition by number, it is only calculated among individuals feeding on a particular prey item, and is calculated at the population (or for this study, age group) level.

A multivariate approach was used for statistical evaluation of ontogenetic shifts in prey consumption and dietary overlap among individuals of various ages. Prey abundance data were pooled among higher taxonomic units for this analysis. A Bray-Curtis dissimilarity matrix was used to develop a multivariate model for evaluating variability in diet composition among Age-0, Age-1, and Age-2 or greater yellow perch. The BrayCurtis distance was selected over other dissimilarity measures because it is not partial to data that are lacking across multiple response variables, commonly referred to as "double zeros" (Faith et al. 1987). All statistical computations were conducted with the $\mathrm{R}$ language and environment for statistical computing Version 2.15.2 (R Development Core Team 2012). Pseudo-F distributions formulated from 999 permutations of Bray-Curtis distances were used for calculating statistical probabilities. Permutational multivariate analysis of variance using distance matrices (Adonis) was used to model multivariate responses of prey abundance as a function of the categorical age groups. (McArdle and Anderson 2001; Anderson 2001, Anderson 2006). Analysis of variance (ANOVA) was used to test for homogeneity of multivariate spread between each of the three factor levels (Anderson et al. 2006). Nonparametric multidimensional scaling (NMDS) was used to plot diet composition among age groups in multivariate space. Confidence ellipses (95\%) were placed around the centroid for each age group. 


\section{Results}

\section{Evaluation of Sex, Size Structure, Age Structure, Mortality, and Condition}

The sample included 271 yellow perch, and females $(n=175)$ were more abundant than males $(n=57)$. Lengths of young-of-year individuals $(n=39)$ ranged from $66-96 \mathrm{~mm}$ TL $($ mean $=81.38)$. Males ranged in size from 128-280 mm TL $($ mean $=198.89)$, and females ranging from $115-320 \mathrm{~mm}$ TL $($ mean $=211.50)$ were present in the sample. Length-frequency distributions showed smaller individuals normally distributed around distinct peaks, representing Age-0 and Age-1 individuals; however, distinction between age-cohorts diminishes among larger individuals (Figure 1).

The Gabelhouse (1984) five-cell length classification system was used to summarize length data by stock- $(130 \mathrm{~mm})$, quality- $(200 \mathrm{~mm})$, preferred- $(250 \mathrm{~mm})$, memorable- $(300 \mathrm{~mm})$ and trophy-lengths $(380 \mathrm{~mm})$. Data are listed as number of individuals (percent of total sample) exceeding length categories: 226 (83.4) stock, 137 (50.6) quality, 41 (15.1) preferred, and 6 (2.2) memorable. No yellow perch larger than trophy-length were included in the sample. A total of 57 males were included in the: 56 (98.3) stock, 29 (50.9) quality, and 7 (12.3) preferred. No males were larger than the defined size for memorable-length yellow perch. The sample included 175 females: 171 (97.7) stock, 109 (62.3) quality, 28 (21.7) preferred, and 6 (3.4) memorable.

Proportional size distributions $\left(\mathrm{PSD}_{\mathrm{x}}\right)$ were calculated as numerical descriptors of length-frequency data; where $x$ represents Gablehouse (1984) categories for individuals exceeding quality- (Q), preferred- (P), and memorable-lengths (M). No trophy-length individuals were included in the sample, and $\mathrm{PSD}_{\mathrm{T}}$ was not determined. Values are listed 
as $\mathrm{PSD}_{\mathrm{x}}=$ estimate $(95 \%$ confidence intervals $): \mathrm{PSD}=61(54.4-67.1), \mathrm{PSD}_{\mathrm{P}}=19(13.5-$ 23.6), and $\mathrm{PSD}_{\mathrm{M}}=3(0.56-4.7)$.

The relationship between weight and length was evaluated using the power model: $W=a L^{b}$. Parameter estimates derived from weight-length regression in the FAMS software were $a=-5.457$ and $b=3.20$. The parameter estimate $b(3.20)$ is indicative of allometric growth, in which the individuals change body shape occurs. A positive value suggests a transformation to a more rotund body-from with the addition of length in individuals.

An agreement rate of $96.8 \%$ occurred between the two readers during age estimation. Individuals ranged in age from Age $0(n=39)$ to Age $9(n=2)$. Age-frequency distributions (Figure 2) suggest an under-representation of Age-0 and Age-1 individuals among the data. Age-7 yellow perch $(n=13)$ were more abundant than both Age-5 $(n=10)$ and Age-6 (n=5) individuals. Males $(n=57)$ and females $(n=175)$ were present among all year-classes collected, with the exception of the oldest age group (Age-9) comprised of two female yellow perch.

Weighted linear regression based on number-at-age data was used to fit a weighted catch curve (Figure 3). The fitted catch curve was used to estimate instantaneous mortality rate $(Z=-0.459)$ and annual survival rate $(S=63 \%)$. Homogeneity in error variance was not supported by the residual plot of the fitted linear regression, indicating that one or more of the assumptions of catch curve analysis were not met.

Relative weight $\left(W_{r}\right)$ was calculated for yellow perch exceeding $100 \mathrm{~mm}$ TL (Table 1). Mean $W_{r}$ for individuals greater than $100 \mathrm{~mm}$ TL $(\mathrm{n}=251)$ was 74 . Gender- 
specific differences in $W_{r}$ were observed between sub-stock ( $\left.<130 \mathrm{~mm}\right)$ individuals: males $\left(W_{r}=68\right)$ and females $\left(W_{r}=78\right)$. No other differences were observed among the data.

\section{Growth Modeling}

Length-at-age data were collected from 271 yellow perch from Cheat Lake, with varying ages (0-9) and lengths $(66-320 \mathrm{~mm})$. Females $(\mathrm{n}=157)$ attained larger maximum lengths than males $(\mathrm{n}=57)$. Some individuals, both male and female, approached asymptotic lengths at Age-4 (Figure 4). Four growth models were fitted to mean lengthat-age data (Figure 5). The von Bertalanffy growth model $\left(w_{i}=0.64\right)$ was selected as the best model for representing somatic growth of Cheat Lake yellow perch (Table 2). However, $\mathrm{AIC}_{\mathrm{c}}$ provided some evidence in support of the Gompertz model $\left(w_{i}=0.34\right.$ and $\Delta=1.28$ ). The von Bertalanffy growth model predicted a larger asymptotic length than both the Gompertz and logistic models (Table 3).

\section{Comparative Analysis of Growth Rates}

Based on the relative growth index (Jackson et al. 2008), this population exhibits excellent growth $(\mathrm{RGI}=137.03)$. Of the ages $(1-6)$ for which Jackson et al. (2008) described growth percentiles, Cheat Lake yellow perch were commonly in the $75^{\text {th }}$ percentile or greater (Table 4). Comparison of the standard length equation $\left(L_{s}\right)$ for yellow perch and constrained von Bertalanffy growth model (VBGM) fitted to mean length-at-age data (Figure 6) illustrate exceptional growth for Cheat Lake yellow perch. Parameter estimates for asymptotic length $\left(\mathrm{L}_{\infty}\right)$ and growth rates $(k)$ are listed for each model: $L_{s}\left(\mathrm{~L}_{\infty}=280.5, k=0.3320\right)$ and VBGM $\left(\mathrm{L}_{\infty}=279.7, k=0.5960\right)$.

\section{Compositional Diet Analysis}

Summer diet composition was evaluated for 252 yellow perch. Individuals were grouped into three age categories: Age- $0(n=22)$, Age-1 $(n=47)$, and Age- $2^{+}(n=177)$. 
Individuals with empty stomachs and those including unidentifiable prey items were excluded from the diet analysis. Of the 22 Age-0 individuals, 3 (13.6\%) were empty. Among the 47 Age-1 individuals, $5(10.6 \%)$ were empty, and 1 (2.1\%) contained an unidentifiable prey item. Of the 177 Age-2 individuals, 46 (25.8\%) were empty, and 1 $(0.56 \%)$ contained an unidentifiable prey item. Thus, 190 individuals were included in diet analyses: Age-0 $(n=19)$, Age-1 $(n=41)$, and Age-2 $(n=130)$. Percent frequency of occurrence $\left(O_{i}\right)$, mean percent composition by number $\left(M N_{i}\right)$, and prey-specific abundance $\left(P_{i}\right)$ were calculated as quantitative measures describing diet composition among the three age groups (Table 5).

Zooplankton (primarily Copepods) were present among all Age-0 individuals, on average accounting for $85.3 \%$ of all prey types consumed, and numerically comprising 99.0\% of all stomach contents. Trichoptera were also commonly consumed by Age-0 yellow perch, occurring in $21.1 \%$ of individuals and accounting for $46.7 \%$ of all prey items identified from fish that had Trichoptera in their stomachs. Diptera (mostly Chaoborus spp.) were present among 10.5\% of all Age-0 individuals and comprised $45.5 \%$ of the all prey items incorporated in the diets for which they were present. However, considering the numerical abundance of total prey types identified among all Age-0 individuals, Trichoptera and Diptera accounted for less than $10 \%$ of the diet.

Trichoptera were found in $63.4 \%$ of all Age-1 yellow perch, typically accounting for $43.4 \%$ of the diet, and comprising $46.7 \%$ of the diets of yellow perch in which they were identified. Diptera (primarily chironomids) were found in $61.0 \%$ of all Age-1 individuals, and accounted for $20.8 \%$ of all prey items consumed by Age-1 individuals. 
Bivalvia were present in $17.1 \%$ of Age-1 yellow perch, and among the individuals that had consumed them, Bivalvia comprised $10.8 \%$ of the diet on average.

The diet composition among Age- $2^{+}$individuals was more diverse than the other two age groups. Fishes were found among the stomach contents of $41.5 \%$ of Age- $2^{+}$ individuals, and numerically accounted for $30.7 \%$ of all prey items consumed. Trichoptera were identified from $33.1 \%$ of all Age- $2^{+}$yellow perch, and accounted for $73.1 \%$ of the prey items found in the stomachs of individuals that had consumed Trichoptera. Diptera (mostly Chironomidae) were consumed by $36.2 \%$ of Age- $2^{+}$yellow perch, $12.1 \%$ of all prey items, and $22.0 \%$ of all prey items present in the stomachs of individuals that had consumed Diptera. Sialidae were also commonly consumed by Age$2^{+}$individuals, numerically accounting for $53.0 \%$ of all prey items in the stomachs of Age$2^{+}$individuals that had consumed them. Zooplankton (mostly Cladocerans and Ostracods) was only found in $1.5 \%$ of Age- $2^{+}$yellow perch. However, zooplankton accounted for $70.0 \%$ of the stomach contents for the few individuals in which zooplankton were identified.

Results from Adonis illustrated significant differences in diet composition between the three age groups $(\mathrm{p}=0.001)$. However, the assumption for homogeneity in multivariate dispersion of prey types was rejected by the ANOVA ( $<<0.001)$, possibly suggesting a false detection of significance from the Adonis model. However, given the high numerical abundance of various prey items among yellow perch and variation observed from quantitative indices, differences likely exist. Confidence ellipses (95\%) placed around the centroid of each age group in the ordination of multivariate prey items (Figure 6) reiterate dietary trends reported by quantitative indices. The abundance of 
zooplankton in young-of-year individuals separates Age-0 yellow perch from older age groups. Some overlap and prey resources utilized by Age- 1 and Age- $2^{+}$individuals were observed. However, the $95 \%$ confidence ellipse for Age- $2^{+}$individuals was significantly influenced by piscivory.

\section{Discussion}

Exceptional growth rates were observed among Cheat Lake yellow perch. Rapid growth is likely responsible for high percentages of stock- (83.4\%) and quality- (50.6\%) length individuals within the sample $(\mathrm{n}=271)$. Growth parameters estimated in this study suggest that individuals are commonly recruited into the fishery by Age-2, assuming a quality-length of $200 \mathrm{~mm}$. Calculated PSD for Cheat Lake yellow perch was 61, wellexceeding the PSD values (30-50) recommended by Anderson and Weithman (1978) for a balanced population. Cheat Lake occurs near the southern limits for the native range of yellow perch, and latitudinal variability may be a factor largely contributing to the growth rates determined in this study. Because of higher annual temperatures and longer day lengths, Cheat Lake yellow perch likely have an extended growing season relative to populations occurring at more northern latitudes.

Rapid growth was observed among both male and female yellow perch. However, females grew faster and achieved larger maximum sizes than males, a trend well documented among populations of yellow perch. In Cheat Lake, gender-specific differences in growth rates were observed among Age-2 individuals. In comparison to females $(n=175)$, males $(n=57)$ were largely under-represented in the sample. This may be 
a artifact associated with the electrofishing gear, and the sample may not be a true representation of sex ratios present within the population.

An annual survival rate of $63 \%$ for the population was estimated from the weighted catch-curve. However, variability among residuals of the fitted linear model suggests one or more assumption violations associated with catch-curve analysis. Inconsistencies between residuals often result from non-constant rates of recruitment and year-class strength (Maceina 1997; Slipke and Maceina 2010). Patterns observed among the residuals may suggest that high recruitment occurred in 2005, explaining the high abundance of Age-7 individuals in the sample.

Of the 271 yellow perch included in this study, few individuals ( $n=6)$ exceed the memorable-length (300 mm TL) proposed by Gabelhouse (1984). Although exceptional growth rates were observed, asymptotic growth may frequently be achieved by Age-4 individuals. Selective harvest by recreational anglers has been shown to alter lengthfrequencies in population through constant removal of faster growing individuals (Lee 1920; Isley and Grabowski 2007). Some authors have also suggested that competition, expressed as the abundance of all species within a fish community, can negatively influence growth rates in yellow perch (Boisclair and Leggett 1989a, 1989b, 1989c; Boisclair and Rassmussen 1996). The assemblage of games species in Cheat Lake is relatively diverse, and interspecific competition for prey resources may limit growth rates of older individuals. However, growth and size structure of yellow perch in Cheat Lake are likely governed by several interacting biotic and abiotic factors, such as intraspecific competition, prey availability, and thermal stress associated with annual water temperatures. 
A mean relative weight $\left(W_{r}\right)$ of 74 was calculated for Cheat Lake yellow perch, which is very low for a population experiencing such rapid growth. However, when developing the standard weight equation for yellow perch, Willis et al. (1991) acknowledged a geographic trend in $W_{r}$ values among populations. Apart from Oneida Lake in New York, eastern populations had a consistently lower $W_{r}$ than populations located in the plains regions. Willis et al. (1991) suggested agricultural production in midwestern states may be partially responsible for this geographic variability, and a mean $W_{r}$ of 84 (63-109) was determined for the nine populations from Ohio, Pennsylvania, and Virginia incorporated in their analyses. The $W_{r}$ of 74 calculated from Cheat Lake may be typical among eastern populations.

The von Bertalanffy growth model is the most frequently used function for estimating growth in fishes. However, model-based biases may result from a priori acceptance of the von Bertalanffy growth model. Failure to consider other models can potentially result in an inaccurate representation of growth (Patterson et al. 2001; Schnute and Richards 2001; Lin and Tzeng 2009). For this study four models were fitted to mean length-at-age data from 271 yellow perch. $\mathrm{AIC}_{\mathrm{c}}$ selected the von Bertalanffy growth model as the best model to represent somatic growth of yellow perch in Cheat Lake. However, there was also evidence supporting the Gompertz model. As an alternative to assuming the von Bertalanffy model is a 'true' representation of growth, researchers should consider other models when estimating growth in fishes.

Multivariate statistics provided evidence suggesting the partitioning of prey resources utilized by three age groups of yellow perch, providing evidence for ontogenetic changes in diet composition. Zooplankton was the most important prey item for Age-0 
individuals. Some dietary overlap occurred between Age-1 and Age-2 ${ }^{+}$individuals. However, fishes were identified from stomach contents of $41.5 \%$ of all Age- $2^{+}$ individuals. Gape limitation is likely responsible for reduced piscivory observed among Age-1 individuals. Authors have suggested Chironomid larvae as a fundamental component of yellow perch diet among populations (Paxton et al. 1978, Lott et al. 1996; Fullhart et al. 2002). Although Chironomidae occurred among the diets of Cheat Lake yellow perch, larger macroinvertebrate preys (Trichoptera, Sialidae, and Bivalvia) were also frequently identified from stomach contents. From an energetic perspective, higher caloric content of larger macroinvertebrate prey is likely a contributing factor to the enhanced somatic growth rates observed by yellow perch in this study.

\section{Management Implications}

Cheat Lake is one of only a few reservoirs in West Virginia that supports a yellow perch fishery, and management considerations regarding this unique fishery have been limited by insufficient information. Although conclusions derived from data obtained during a single season are temporally limited, results from this study offer valuable information regarding various population-based attributes for yellow perch in Cheat Lake. If considered, data obtained from this investigation could aid future management decisions pertaining to this fishery. However, information regarding recruitment, angler harvest rates, and population size are still needed. Future studies investigating factors influencing population dynamics of this fishery could provide useful information for management considerations. Once enforced, the effectiveness of harvest regulations should be evaluated through continued monitoring of the population, and management practices should be adapted to maintain the stability of the fishery (McMullin and Pert 2010). 
Information regarding summer diet composition of Cheat Lake yellow perch was obtained in this study. However, yellow perch feed throughout the year, and data presented here are limited to a single season. Future research could compare seasonal effects on prey items consumed by individuals within this population. Information regarding prey availability could be useful in determining if yellow perch are selecting various prey types. 


\section{Literature Cited}

Ajemian, M. J., and S. P. Powers. 2012. Habitat-specific feeding by cownose rays (Rhinoptera bonasus) of the northern Gulf of Mexico. Environmental Biology of Fishes 95:79-97.

Akaike, H. 1973. Information theory and an extension of the maximum likelihood principle. Pages 267-281 in B. N. Petrov and F. Csaki, editors. Second International Symposium on Information Theory. Akademiai Kiado, Budapest.

Allen, M. S., and J. E. Hightower. 2010. Fish population dynamics: mortality, growth, and recruitment. Pages 43-79 in W. A. Hubert, and M. C. Quist, editors. Inland fisheries management in North America, 3rd edition. American Fisheries Society, Bethesda, Maryland.

Amundson, P. A., H. M. Gabler, and F. J. Staldvik. 1996. A new approach to graphical analysis of feeding strategy from stomach contents data - modification of the Costello method. Journal of Fish Biology 48:607-614.

Anderson, M. J. 2001. A new method for non-parametric multivariate analysis of variance. Austral Ecology 26:32-46.

Anderson, M. J. 2006. Distance-based tests for homogeneity of multivariate dispersions. Biometrics 62:245-253.

Anderson, M. J., K. E. Ellingsen and B. H. McArdle. 2006 Multivariate dispersion as a measure of beta diversity. Ecology Letters 9:683-693.

Anderson, R. O. 1976. Management of small warmwater impoundments. Fisheries 1(6):57, 26-28.

Anderson, R. O., and A. S. Weithman. 1978. The concept of balance for coolwater fish populations. American Fisheries Society Special publication 11:371-381.

Anderson, R. O., and R. M. Neumann. 1996. Length, weight, and associated structural indices. Pages 447-482 in B. R. Murphy and D. W. Willis, editors. Fisheries techniques, $2^{\text {nd }}$ edition. American Fisheries Society, Bethesda, Maryland.

Blackwell, B. G., and T. M. Kaufman. 2012. Timing of yellow perch otolith annulus formation and relationship between fish and otolith lengths. North American Journal of Fisheries Management 32:239-248.

Boisclair, D., and W. C. Leggett. 1989a. Among population variability of fish growth, I. Influence of quantity of food consumed. Canadian Journal of Fisheries and Aquatic Sciences 46:457-467. 
Boisclair, D., and W. C. Leggett. 1989b. Among population variability of fish growth, II. Influence of prey type. Canadian Journal of Fisheries and Aquatic Sciences 46:468-482.

Boisclair, D., and W. C. Leggett. 1989c. Among population variability of fish growth, III. Influence of fish community. Canadian Journal of Fisheries and Aquatic Sciences 46:1539-1550.

Boisclair, D., and J. B. Rasmussen. 1996. Empirical analysis of the influence of environmental variables associated with lake eutrophication on perch growth, consumption, and activity rates. Annales Zoologici Fennici 33:507-515.

Bowen, S. H. 1996. Quantitative description of the diet. Pages 423-471 in B. R. Murphy and D. W. Willis, editors. Fisheries techniques, $2^{\text {nd }}$ edition. American Fisheries Society, Bethesda, Maryland.

Brofka, W. A., and J. Marsden. 1993. A survey of sport fishing in the Illinois portion of Lake Michigan. Annual Report to the Illinois Department of Conservation, Aquatic Ecology Technical Report 93/4, Champaign.

Brown, T., B. Runciman, M. Bradford, and S. Pollard. 2009. A biological synopsis of yellow perch (Perca flavescens). Canadian Manuscript Report of Fisheries and Aquatic Sciences 2883: v-28.

Burnham, K. P., and D. R. Anderson. 2002. Model selection and multimodel inference: A practical information-theoretic approach, $2^{\text {nd }}$ edition. Springer, New York.

Carlson, A. J., and D. A. Isermann. 2010. Mandatory catch and release and maximum length limits for largemouth bass in Minnesota: is exploitation still a relevant concern? North American Journal of Fisheries Management 30:209-220.

Chipps, S. R., and J. E. Garvey. 2007. Assessment of diets and feeding patterns. Pages 473-514 in C. S. Guy and M. L. Brown, editors. Analysis and interpretation of freshwater fisheries data. American Fisheries Society, Bethesda, Maryland.

Clarke, K. R. 1993. Non-parametric multivariate analyses of changes in community structure. Austalian Journal of Ecology 18:117-143.

Costello, M. J. 1990. Predator feeding strategy and prey importance: a new graphical analysis. Journal of Fish Biology 36:261-263.

Craig, J. F. 2000. Percid fishes: systematics, ecology and exploitation. Blackwell Science, Oxford. 
DeVries, D. R. and R. V. Frie. 1996. Determination of age and growth. Pages 483-512 in B. R. Murphy and D. W. Willis, editors. Fisheries techniques, $2^{\text {nd }}$ edition. American Fisheries Society, Bethesda, Maryland.

Doxtater, G. D. 1963. Use of ice water to prevent regurgitation of stomach contents of fish. Transactions of the American Fisheries Society 92:68-69.

Engel, S. 1974. Effects of formalin and freezing on length, weight and condition factor of cisco and yellow perch. Transactions of the American Fisheries Society 103:136138.

Faith D. P., P. R. Minchin, and L. Belbin. 1987. Compositional dissimilarity as a robust measure of ecological distance. Plant Ecology 69:57-68.

Freund, J. G., and J. T. Petty. 2007. Response of fish and macroinvertebrate bioassessment indices to water chemistry in a mined Appalachian watershed. Environmental Management 39:707-720.

Fullhart, H. G., B. G. Parsons, D. W. Willis, and J. R. Reed. 2002. Yellow perch piscivory and its possible role in structuring littoral zone fish communities in small Minnesota lakes. Journal of Freshwater Ecology 17:37-43.

Gabelhouse, D. W., Jr. 1984. A length-categorization system to assess fish stocks . North American Journal of Fisheries Management 4:273-285.

Garvey, J. E., and S. R. Chipps. 2012. Diets and energy flow. Pages 733-779 in A. V. Zale, D. L. Parrish, and T. M. Sutton, editors. Fisheries techniques, $3^{\text {rd }}$ edition. American Fisheries Society, Bethesda, Maryland.

Goeman, T. J., P. D. Spencer, and R. B. Pierce. 1993. Effectiveness of liberalized bag limits as management tools for altering northern pike population structure. North American Journal of Fisheries Management 13:621-624.

Gompertz, B. 1825. On the nature of the function expressive of the law of human mortality and on a new mode of determining the value of life contingencies. Philosophical Transactions of the Royal Society of London 115:515-585.

Griffiths S. P., P. M. Kuhnert, G. F. Fry, F. J. Manson. 2009. Temporal and size-related variation in the diet, consumption rate, and daily ration of mackerel tuna (Euthynnus affinis) in neritic waters of eastern Australia. ICES Journal of Marine Science 66:720-733. 
Guy, C. S., and D. W. Willis. 1991. Evaluation of largemouth bass-yellow perch communities in small South Dakota impoundments. North American Journal of Fisheries Management 11:43-49.

Guy, C. S., R. M. Neumann, D. W. Willis, and R. O. Anderson. 2007. Proportional size distribution (PSD): a further refinement of population size structure index terminology. Fisheries 32:348.

Hanson, J. M., and W. C. Leggett. 1986. Effect of competition between two freshwater fishes on prey consumption and abundance. Canadian Journal of Fisheries and Aquatic Sciences. 43: 1363-1372.

Hasler, A. D. and J. R. Villemonte. 1953. Observations on the daily movement of fishes. Science 118:321-322.

Hayes, D. B, and W. W. Taylor. 1994. Changes in the composition of somatic and gonadal tissues of yellow perch following white sucker removal. Transactions of the American Fisheries Society 123:204-216.

Heath, D., and D. A. Roff. 1987. Test of genetic differentiation in growth of stunted and nonstunted populations of yellow perch and pumpkinseed. Transactions of the American Fisheries Society 116:98-102.

Heibo, E., C. Magnhagen, and L. A. Vøllestad. 2005. Latitudinal variation in life-history traits in Eurasian perch. Ecology 86:3377-3386.

Hile, R., and F. W. Jobes. 1942. Age, growth, and production of the yellow perch, Perca flavescens (Mitchill), of Saginaw Bay. Transactions of the American Fisheries Society 70:102-122.

Hurvich, C. M., and C. L. Tsai. 1989. Regression and time series model selection in small samples. Biometrika 76:297-307.

Isermann, D. A., D. W. Willis, B. G. Blackwell, and D. O. Lucchesi. 2007. Yellow perch in South Dakota: population variability and predicted effects of creel limit reductions and minimum length limits. North American Journal of Fisheries Management 27:918:931

Isermann, D. A., and C. P. Paukert. 2010. Regulating harvest. Pages 185-212 in W. A. Hubert, and M. C. Quist, editors. Inland fisheries management in North America, 3rd edition. American Fisheries Society, Bethesda, Maryland.

Isley, J. J., and T. B. Grabowski. 2007. Age and growth. Pages 187-228 in C. S. Guy and M. L. Brown, editors. Analysis and interpretiation of freshwater fisheries data. American Fisheries Society, Bethesda, Maryland. 
Jackson, Z. J., M. C. Quist, and J. G. Larscheid. 2008. Growth standards for nine North American fish species. Fisheries Management and Ecology 15:107-118.

Jenkins, R. E., and N. M. Burkhead. 1993. Freshwater Fishes of Virginia. American Fisheries Society, Bethesda, Maryland.

Jessup, B. K., A. Markowitz, J. B. Stribling, E. Friedman, K. Labelle, and N. Dziepak. 2003. Family-level key to the stream invertebrates of Maryland and surrounding areas, $3^{\text {rd }}$ edition. Maryland Department of Natural Resources Publication CBWPMANTA-EA-99-2 (rev.2003), Annapolis, Maryland.

Johnson, J. E., and B. L. Swanson. 1974. Length and weight changes of preserved black crappie and yellow perch. The Progressive Fish-Culturist 36:201-206.

Katsanevakis, S. 2006. Modelling fish growth: Model selection, multi-model inference and model selection uncertainty. Fisheries Research 81:229-235.

Katsanevakis, S. and C. Maravelias. 2008. Modeling fish growth: multi-model inference as a better alternative to a priori using von Bertalanffy equation. Fish and Fisheries 9:178-187.

Kraft, C. E., and B. L. Johnson. 1992. Fyke-net and gill-net size selectivities for yellow perch in Green Bay, Lake Michigan. North American Journal of fisheries Management 12:230-236.

Legendre P., and E. D. Gallagher. 2001. Ecologically meaningful transformations for ordination of species data. Oecologia 129:271-280.

Lee, R.M. 1920. A review of the methods of age and growth determination in fishes by means of scales. Fishery Investigations, Series II, Marine Fisheries, Great Britain Ministry of Agriculture, Fisheries and Food 4:1-35.

Lin, Y. J., and W. N. Tzeng. 2009. Modeling the growth of Japanese eel Anguilla japonica in the lower reach of the Kao-Ping River, southern Taiwan: an information theory approach. Journal of Fish Biology 75:100-112.

Lott, J. P., D. W. Willis, and D. O. Lucchesi. 1996. Relationship of food habits to yellow perch growth and population structure in South Dakota lakes. Journal of Freshwater Ecology 11:27-37.

Lucchesi, D., and B. Johnson. 2006. Evaluation of scales and otoliths for walley and yellow perch age estimation. South Dakota Department of Game, Fish, and Parks, Special Report F-21-R-36-38. 
Maceina, M. J. 1997. Simple application of using residuals from catch-curve regression to assess year-class strength in fish. Fisheries Research 32:115-121.

Malison J. A., J. A. Held, and S. E. Kaatz. 2011. Sex determination of yellow perch by external morphology. North American Journal of Aquaculture 73:285-287.

McArdle, B. H. and M. J. Anderson. 2001. Fitting multivariate models to community data: A comment on distance-based redundancy analysis. Ecology 82:290-297.

McCarty, J. P. 1990. Diel periodicity of movement and feeding of yellow perch (Perca flavescens) in Lake Mendota, Wisconsin. Transactions of the Wisconsin Academy of Sciences, Arts and Letters 78:65-76.

McClurg, S. E., J. T. Petty, P. M. Mazik, and J. L. Clayton. 2007. Stream ecosystem response to limestone treatment in acid impacted watersheds of the Allegheny Plateau. Ecological Applications 17:1087-1104.

McMullin, S. L., and E. Pert. 2010. The process of fisheries management. Pages 133-155 in W. A. Hubert and M. C. Quist, editors. Inland Fisheries Management in North America, $3^{\text {rd }}$ edition. American Fisheries Society, Bethesda, Maryland.

McPhail, J. D. 2007. Freshwater fishes of British Columbia. University of Alberta Press, Edmonton.

Merovich, G. T., J. M. Stiles, J. T. Petty, J. Fulton, and P. F. Ziemkiewicz. 2007. Water chemistry based classification of streams and implications for restoring mined Appalachian watersheds. Environmental Toxicology and Chemistry 26:1361-1369

Merritt, R. W., K. W. Cummins, and M. B. Berg, editors. 2008. Aquatic Insects of North America, $4^{\text {th }}$ edition. Kendall-Hunt, Dubuque, Iowa.

Mills, E. L., and J. L. Forney. 1981. Energetics, food consumption, and growth of young yellow perch in Oneida Lake, New York. Transactions of the American Fisheries Society 110:470-488.

Miranda, L. E. 2007. Approximate sample sizes required to estimate length distributions. Transactions of the American Fisheries Society 136:409-415.

Miranda, L. E., and P. W. Bettolli. 2007. Mortality. Pages 229-277 in C. S. Guy and M. L. Brown, editors. Analysis and interpretation of freshwater fisheries data. American Fisheries Society, Bethesda, Maryland.

Munro, C. L., and J. L. MacMillan. 2010. Overpopulation and growth of yellow perch (Perca flavescens) and the potential effect of increased competition on brook trout (Salvelinus fontinalis) in Long Lake, Halifax County, Nova Scotia. Department of 
Fisheries and Aquaculture: Inland Fisheries Division, Report B0K 1H0, Pictou, Nova Scotia.

Murphy, B. R., D. W. Willis, and T. A. Spring. 1991. The relative weight index in fisheries management: status and needs. Fisheries 16:30-38.

Ney, J. J. 1978. A synoptic review of yellow perch and walleye biology. American Fisheries Society Special Publication 11:1-12.

Neumann, R. M., and M. S. Allen. 2007. Size structure. Pages 375-421 in C. S. Guy and M. L. Brown, editors. Analysis and interpretation of freshwater fisheries data. American Fisheries Society, Bethesda, Maryland.

Neumann, R. M., C. G. Guy, and D. W. Willis. 2012. Length, weight, and associated indices. Pages 637-676 in A. V. Zale, D. L. Parrish, and T. M. Sutton, editors. Fisheries techniques, $3^{\text {rd }}$ edition. American Fisheries Society, Bethesda, Maryland.

Niewinski, B. C., and C. P. Ferreri. 1999. A comparison of three structures for estimating the age of yellow perch. North American Journal of Fisheries Management 19:872-877.

Page, L. M., and B. M. Burr. 2011. Peterson field guide to freshwater fishes of North America North of Mexico, $2^{\text {nd }}$ edition. Houghton Mifflin Harcourt, Boston.

Paloheimo, J. E., and L. M. Dickie. 1965. Food and growth of fishes. I. A growth curve derived from experimental data. Journal of the Fisheries Research Board of Canada 22:521-542

Parker, A. D., D. G. Uzarski, and C. R. Ruetz, III, C. R. 2009. Diets of yellow perch (Perca flavescens) in wetland habitats of Saginaw Bay, Lake Huron. Journal of Freshwater Ecology 24:347-355.

Parker, R. R., and P. A. Larkin. 1959. A concept of growth in fishes. Journal of the Fisheries Research Board of Canada 16:721-745.

Patterson, K., B. Cook, C. Darby, S. Cavaris, L. Kell, P. Lewy, N. Mesnil, A. E. Punt, V. Restrepo, D. W. Skagen, and G. Stefansson. 2001. Estimating uncertainty in fish stock assessment and forecasting. Fish and Fisheries 2:125-157.

Paxton, K. O., and F. Stevenson. 1978. Food, growth, and exploitation of percids in Ohio upground reservoirs. American Fisheries Society Special Publication 11:270-277.

Peckarsky, B. L., P. Fraissinet, M. A. Penton, and D. J. Conklin, Jr. 1990. Freshwater macroinvertebrates of Northeastern North America. University Press, Ithaca, NY. 
Pope, K. L., and C. G. Kruse. 2007. Condition. Pages 513-532 in C. S. Guy and M. L. Brown, editors. Analysis and interpretiation of freshwater fisheries data. American Fisheries Society, Bethesda, Maryland.

Purchase, C. F., N. C. Collins, G. E. Morgan, and B. J. Shuter. 2005. Predicting life history traits of yellow perch from environmental characteristics of lakes. Transactions of the American Fisheries Society 134:1369-1381.

Quist M. C., C. S. Guy, R. D. Schultz, and J. L. Stephen. 2003. Latitudinal comparison of walleye growth in North America and factors influencing growth of walleyes in Kansas reservoirs. North American Journal of Fisheries Management 23:677-692.

Quist, M. C., M. A. Pegg, and D. R. DeVries. 2012. Age and growth. Pages 677-731 in A. V. Zale, D. L. Parrish, and T. M. Sutton, editors. Fisheries techniques, $3^{\text {rd }}$ edition. American Fisheries Society, Bethesda, Maryland.

R Development Core Team. 2012. R: A language and environment for statistical computing, reference index version 2.15.2. R Foundation for Statistical Computing, Vienna, Austria. ISBN 3-900051-07-0. Available: http://www.Rproject.org.

Robillard, S. R., and E. J. Marsden. 1996. Comparison of otolith and scales ages for yellow perch from Lake Michigan. Journal of Great Lakes Research 22:429-435.

Roff, D. A. 1980. A motion for the retirement of the von Bertalanffy function. Canadian Journal of Fisheries and Aquatic Sciences 37:127-129.

Sandheinrich, M. B., and W. A. Hubert. 1984. Intraspecific resource partitioning by yellow perch in a stratified lake. Canadian Journal of Fisheries and Aquatic Sciences 41:1745-1752.

Schnute, J. T. 1981. A versatile growth model with statistically stable parameters. Canadian Journal of Fisheries and Aquatic Sciences 38:1128-1140.

Schnute, J. T. and L. J. Richards. 2001. Use and abuse of fishery models. Canadian Journal of Fisheries and Aquatic Sciences 58:10-17.

Schoenbeck, C. W., and M. L. Brown. 2009. Potential importance of competition, predation, and prey on yellow perch growth from two dissimilar population types. The Prairie Naturalist 42:32-37.

Scott, D. C. 1955. Activity patterns of perch. Ecology 36:320-327.Smith, D. G., editor. 2001. Pennak's freshwater invertebrates of the United States: Porifera to Crustacea, $4^{\text {th }}$ edition. Wiley, New York. 
Slipke, J. W., and M. J. Maceina. 2010. Fisheries analyses and modeling simulator (FAMS 1.0). American Fisheries Society, Bethesda, Maryland.

Stobo, W. T. 1972. Effects of formalin on the length and weight of yellow perch. Transactions of the American Fisheries Society 101:362-264.

Ursin, E. 1967. A mathematical model of some aspects of fish growth, respiration, and mortality. Journal of the Fisheries Research Board of Canada. 24:2355-2453.

von Bertalanffy, L. 1938. A quantitative theory of organic growth. Human Biology 10:181-213.

Wege, G. J., and R. O. Anderson. 1978 . Relative weight (Wr) : a new index of condition for largemouth bass. Pages 79-91 in G. D. Novinger and J . G. Dillard, editors . New approaches to the management of small impoundments. American Fisheries Society, North Central Division, Special Publication 5, Bethesda, Maryland.

Welsh, S. A., and S. A. Perry. 1997. Acidification and fish occurrence in the upper Cheat River drainage, West Virginia. Journal of the American Water Resources Assocation 33:432-429.

Willis, D. W., C. S. Guy, and B. R. Murphy. 1991. Development and evaluation of a standard weight $(W s)$ equation for yellow perch. North American Journal of Fisheries Management 11:374-380 
Table 1. Total number of individuals (n) and mean relative weight $\left(W_{r}\right)$ among Gabelhouse (1984) five-cell size categories.

\begin{tabular}{|c|c|c|c|c|c|c|c|}
\hline & & $\begin{array}{l}\text { *Sub-stock } \\
(<130 \mathrm{~mm})\end{array}$ & $\begin{array}{c}\text { Stock } \\
(130 \mathrm{~mm})\end{array}$ & $\begin{array}{c}\text { Quality } \\
(200 \mathrm{~mm})\end{array}$ & $\begin{array}{l}\text { Preferred } \\
(250 \mathrm{~mm})\end{array}$ & $\begin{array}{l}\text { Memorable } \\
\text { (>300 mm) }\end{array}$ & Total \\
\hline \multirow{2}{*}{ Total Sample } & $\mathrm{n}$ & 24 & 89 & 96 & 36 & 6 & 251 \\
\hline & Mean Wr & 76 & 74 & 74 & 74 & 74 & 74 \\
\hline \multirow{2}{*}{ Males } & $n$ & 1 & 27 & 25 & 4 & - & 57 \\
\hline & Mean Wr & 68 & 75 & 75 & 72 & - & 72 \\
\hline \multirow{2}{*}{ Females } & $\mathrm{n}$ & 4 & 62 & 71 & 32 & 6 & 175 \\
\hline & Mean Wr & 78 & 74 & 73 & 74 & 74 & 75 \\
\hline
\end{tabular}

* $\mathrm{W}_{\mathrm{r}}$ applicable to yellow perch exceeding $100 \mathrm{~mm}$ TL (Willis et al. 1991), and some individuals (<100 mm) TL were not included. 
Table 2. Number of estimated parameters ( $k$ ), Akaike's Information Criterion corrected for small sample size (AICc), Akaike differences $(\Delta$ ), and Akaike weights ( $w$ ) for four candidate models.

\begin{tabular}{lcccc}
\hline Model & $\boldsymbol{k}$ & AICc & $\Delta$ & $\boldsymbol{W}$ \\
\hline von Bertalanffy & $\mathbf{4}$ & $\mathbf{2 3 9 0 . 2 9}$ & $\mathbf{0 . 0 0}$ & $\mathbf{0 . 6 5}$ \\
Gompertz & $\mathbf{4}$ & $\mathbf{2 3 9 1 . 5 7}$ & $\mathbf{1 . 2 8}$ & $\mathbf{0 . 3 4}$ \\
Logistic & 4 & 2402.66 & 12.37 & 0.00 \\
Power & 4 & 2448.07 & 57.78 & 0.00 \\
\hline
\end{tabular}

Models supported by the data are bolded.

Table 3. Parameter estimates and associated standard error (S. E.) for candidate models.

\begin{tabular}{llrl}
\hline Model & Parameter & Estimate & S. E. \\
\hline von Bertalanffy & $\mathbf{L}_{\infty}(\mathbf{m m})$ & $\mathbf{2 8 3 . 8 0 7}$ & $\mathbf{4 . 8 4 2}$ \\
& k (year-1) & $\mathbf{0 . 4 2 3}$ & $\mathbf{0 . 0 2 3}$ \\
Gompertz & $\mathbf{t}_{\mathbf{0}}$ (year) & $\mathbf{- 0 . 7 7 3}$ & $\mathbf{0 . 0 5 7}$ \\
& $\mathbf{L}_{\infty}(\mathbf{m m})$ & $\mathbf{2 7 2 . 2 5 2}$ & $\mathbf{3 . 6 8 4}$ \\
& k (year-1) & $\mathbf{0 . 6 5 2}$ & $\mathbf{0 . 0 3 0}$ \\
logistic & $\mathbf{t}_{\mathbf{0}}($ year $)$ & $\mathbf{0 . 2 8 3}$ & $\mathbf{0 . 0 4 0}$ \\
& $\mathrm{L}_{\infty}($ mm $)$ & 265.492 & 3.250 \\
& $\mathrm{k}($ year-1) & 0.901 & 0.039 \\
power & $\mathrm{t}_{0}($ year $)$ & 0.837 & 0.044 \\
& $\mathrm{~b}_{0}(\mathrm{~mm})$ & 78.476 & 3.493 \\
& $\mathrm{~b}_{1}($ year -1$)$ & 83.413 & 3.823 \\
& $\mathrm{~B}_{2}$ & 0.463 & 0.021 \\
\hline
\end{tabular}

Models supported by the data are bolded 
Table 4. Relative growth index applied to Cheat Lake yellow perch. Total number (n), standard length estimates $\left(\boldsymbol{L}_{\boldsymbol{s}}\right)$, mean length-at-age $(\overline{\boldsymbol{L}})$, estimated relative growth values (RGI), and percentile are presented.

\begin{tabular}{cccccc}
\hline Age & $\mathbf{n}$ & $\boldsymbol{L}_{\boldsymbol{s}}$ & $\overline{\boldsymbol{L}}$ & $\mathbf{R G I}$ & Percentile \\
\hline 1 & 49 & 81.31 & 142.73 & 175.55 & 90 \\
2 & 76 & 137.58 & 201.76 & 146.65 & 95 \\
3 & 52 & 177.96 & 225.25 & 126.58 & 75 \\
4 & 18 & 206.93 & 243.22 & 117.54 & 75 \\
5 & 10 & 227.71 & 247.30 & 108.60 & 50 \\
6 & 5 & 242.63 & 280.20 & 115.49 & 75 \\
7 & 13 & 253.33 & 267.46 & 105.58 & N/A \\
8 & 7 & 261.00 & 283.86 & 108.76 & N/A \\
9 & 2 & 266.51 & 296.50 & 111.25 & N/A \\
\hline
\end{tabular}


Table 5. Summary of summer diet composition among age groups of yellow perch $(\mathrm{n}=190)$. Data are presented as frequency of occurrence $\left(O_{i}\right)$, mean composition by number $\left(M N_{i}\right)$, and prey-specific abundance $\left(P_{i}\right)$. Yellow perch with empty stomachs and individuals containing unidentifiable prey items were excluded from diet analyses.

\begin{tabular}{|c|c|c|c|c|c|c|c|c|c|}
\hline \multirow{2}{*}{ Prey Type } & \multicolumn{3}{|c|}{$O_{i}$} & \multicolumn{3}{|c|}{$M N_{i}$} & \multicolumn{3}{|c|}{$\boldsymbol{P}_{i}$} \\
\hline & Age-0 & Age-1 & Age- $2^{+}$ & Age-0 & Age-1 & Age-2 $^{+}$ & Age-0 & Age-1 & Age-2 $^{+}$ \\
\hline Zooplankton & 100 & 7.32 & 1.54 & 85.25 & 1.39 & 0.92 & 98.99 & 21.62 & 70.00 \\
\hline Amphipoda & 15.79 & 4.88 & - & 3.98 & 0.66 & - & 25.64 & 14.29 & - \\
\hline Cladocera & 36.84 & 4.88 & 0.77 & 10.02 & 0.58 & 0.66 & 4.90 & 12.00 & 85.71 \\
\hline Copepoda & 68.42 & 2.44 & - & 67.26 & 0.15 & - & 99.59 & 6.25 & - \\
\hline Ostracoda & 10.53 & - & 0.77 & 3.99 & - & 0.26 & 29.41 & - & 33.33 \\
\hline Annelida & - & - & 1.54 & - & - & 0.21 & - & - & 4.26 \\
\hline Hirudinea & - & - & 0.77 & - & - & 0.02 & - & - & 2.33 \\
\hline Oligochaeta & - & - & 0.77 & - & - & 0.19 & - & - & 25.00 \\
\hline Bivalvia & - & 17.07 & 15.38 & - & 3.78 & 5.40 & - & 10.81 & 24.27 \\
\hline Corbiculidae & - & 9.76 & 0.77 & - & 0.57 & 0.64 & - & 3.59 & 83.33 \\
\hline Sphaeriidae & - & 12.20 & 14.62 & - & 3.21 & 4.76 & - & 16.06 & 23.56 \\
\hline Coleoptera & - & - & 3.08 & - & - & 0.92 & - & - & 25.00 \\
\hline Crayfishes & - & - & 10.00 & - & - & 7.14 & - & - & 58.14 \\
\hline Diptera & 10.53 & 60.98 & 36.15 & 5.09 & 20.78 & 12.11 & 45.45 & 20.63 & 22.04 \\
\hline Chaoborus spp. & 10.53 & 14.63 & 1.54 & 4.04 & 6.36 & 0.29 & 36.36 & 35.45 & 5.45 \\
\hline Chironomidae & 5.26 & 56.10 & 34.62 & 1.05 & 13.35 & 11.69 & 20.00 & 13.72 & 21.94 \\
\hline Culicidae & - & 4.88 & 0.77 & - & 0.67 & 0.02 & - & 7.27 & 2.70 \\
\hline Tipulidae & - & 4.88 & 2.31 & - & 0.41 & 0.12 & - & 4.17 & 4.82 \\
\hline Ephemeroptera & 5.26 & - & 8.46 & 0.44 & - & 3.13 & 8.33 & - & 8.28 \\
\hline Fishes & - & 19.51 & 41.54 & - & 9.05 & 30.65 & - & 5.37 & 22.04 \\
\hline Gastropoda & - & 17.07 & 3.08 & - & 6.46 & 0.36 & - & 15.89 & 7.92 \\
\hline Physidae & - & 7.32 & 0.77 & - & 0.42 & 0.01 & - & 7.09 & 1.92 \\
\hline Planorbidae & - & 14.63 & 2.31 & - & 6.04 & 0.34 & - & 9.27 & 9.39 \\
\hline Lepidoptera & - & - & 0.77 & - & - & 0.38 & - & - & 50.00 \\
\hline Nematomorpha & - & 14.63 & 2.31 & - & 1.92 & 2.21 & - & 6.15 & 90.00 \\
\hline Odonata & 5.26 & 14.63 & 9.23 & 0.38 & 12.54 & 3.68 & 7.14 & 72.73 & 21.68 \\
\hline Anisoptera & - & 14.63 & 7.69 & - & 12.54 & 3.43 & - & 72.73 & 23.93 \\
\hline Zygoptera & 5.26 & - & 2.31 & 0.38 & - & 0.25 & 7.14 & - & 9.09 \\
\hline Sialidae & - & 12.20 & 24.62 & - & 0.68 & 12.57 & - & 4.59 & 52.99 \\
\hline Trichoptera & 21.05 & 63.41 & 33.08 & 8.85 & 43.40 & 20.31 & 46.67 & 74.64 & 73.05 \\
\hline
\end{tabular}

Major taxonomic groupings of prey items and associated values are bolded. 


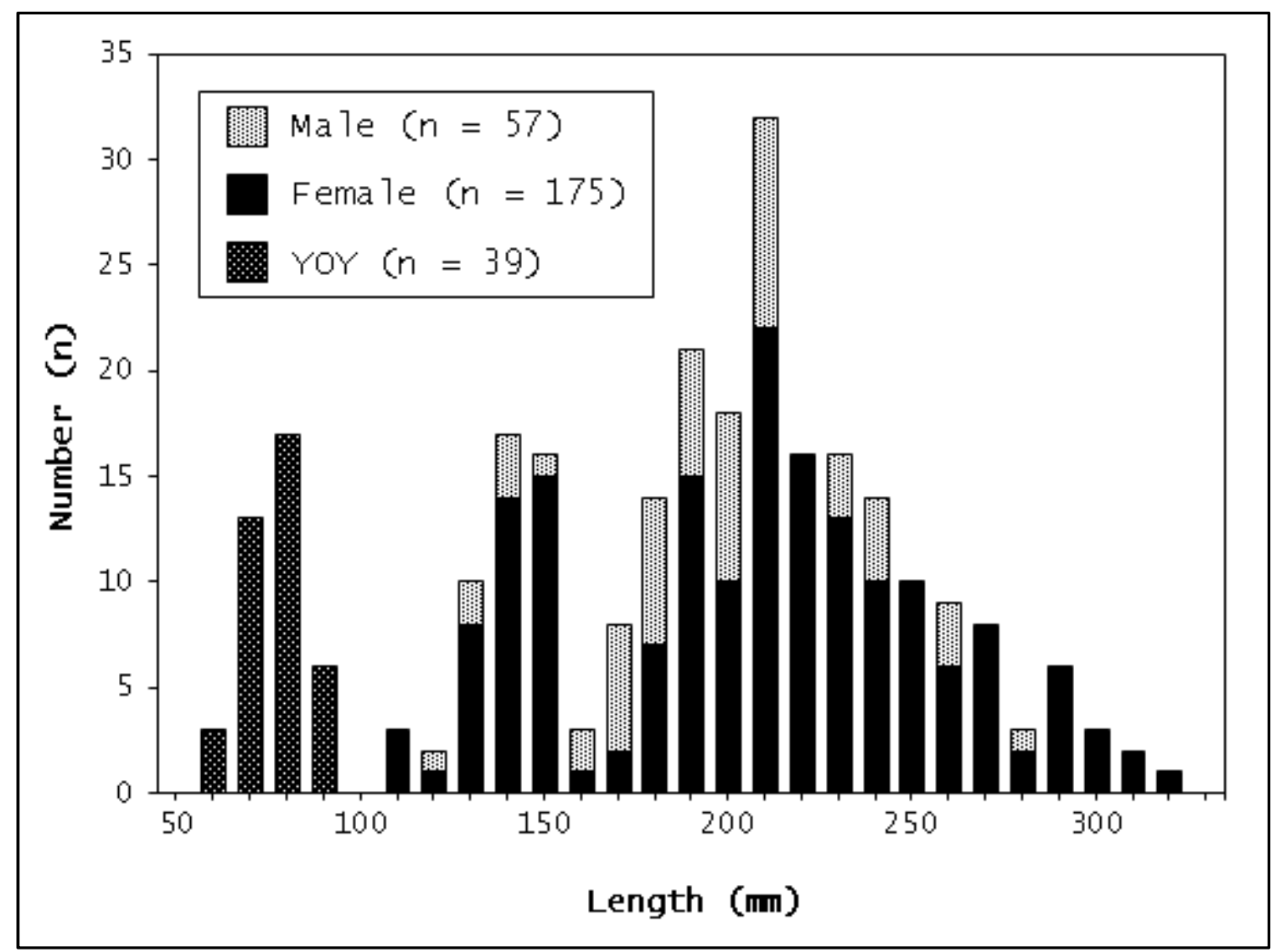

Figure 1. Length-frequency distributions for male, female, and young-of-year (YOY) yellow perch from Cheat Lake, West Virginia $(n=271)$. Individuals grouped into $10-\mathrm{mm}$ size categories. 


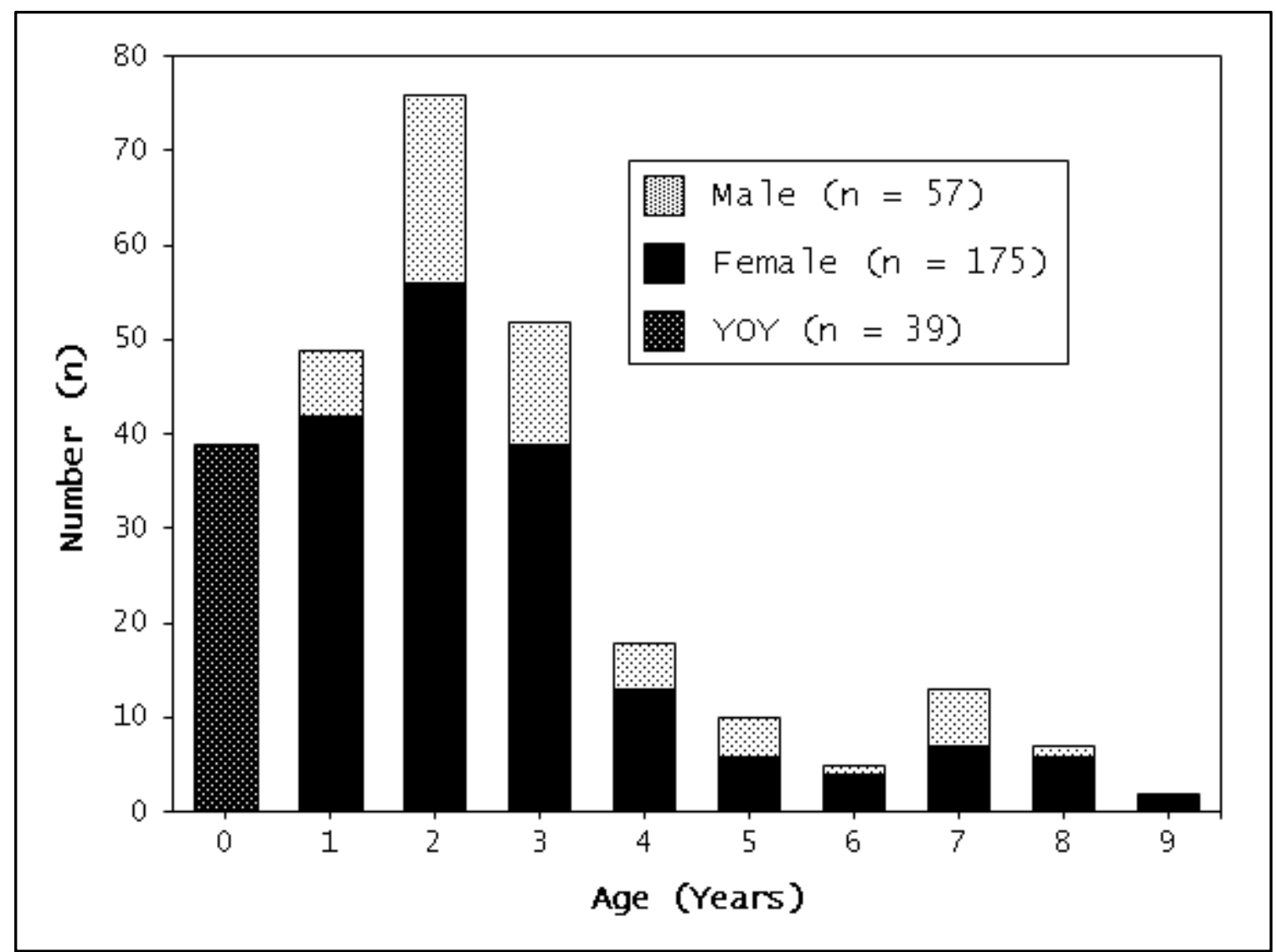

Figure 2. Histogram representing sex-specific distribution of ages among 271 Cheat Lake yellow perch. 


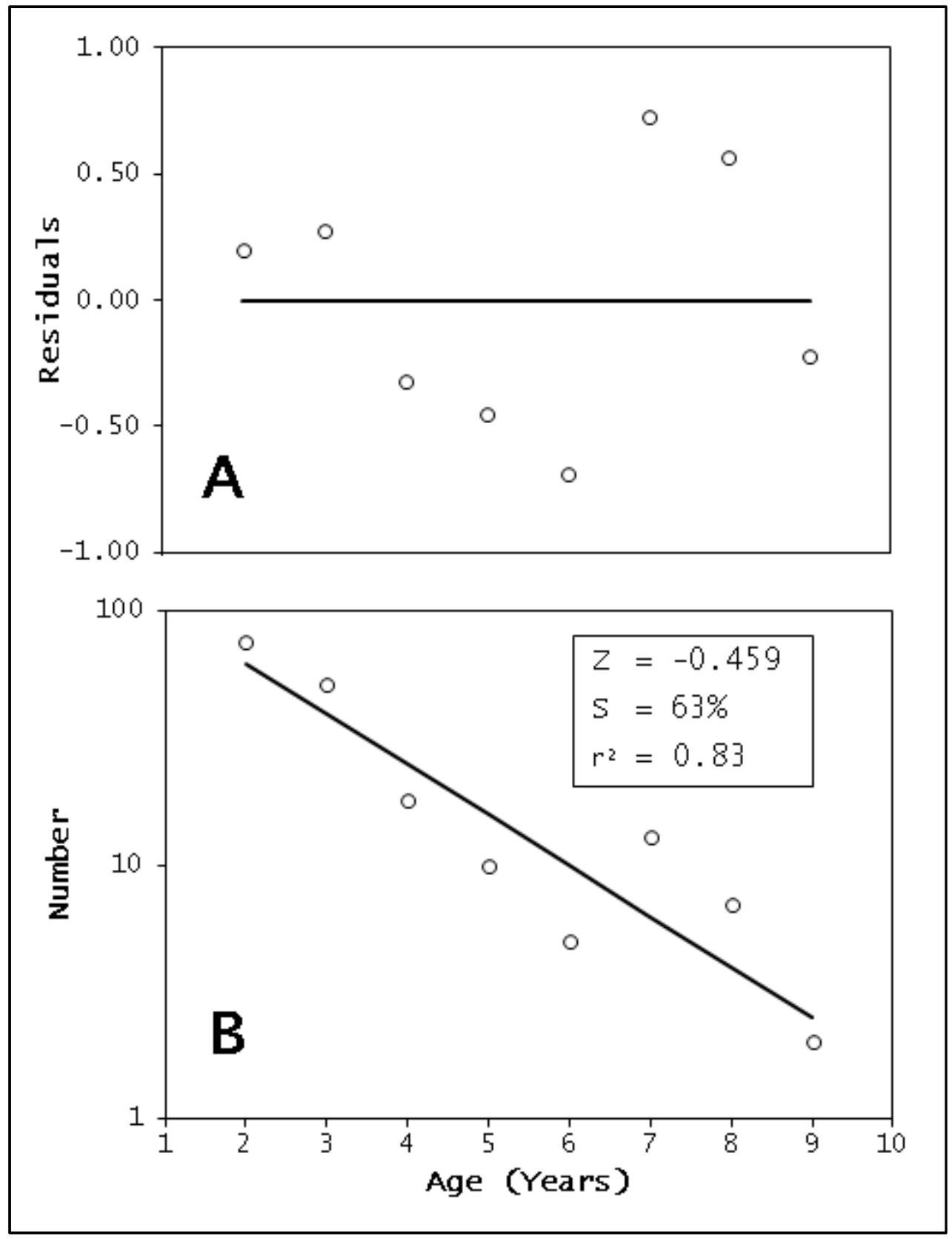

Figure 3. Residual plot (A) and weighted catch curve (B) fitted to numberat-age data for Cheat Lake yellow perch ages 2 to 9 . 


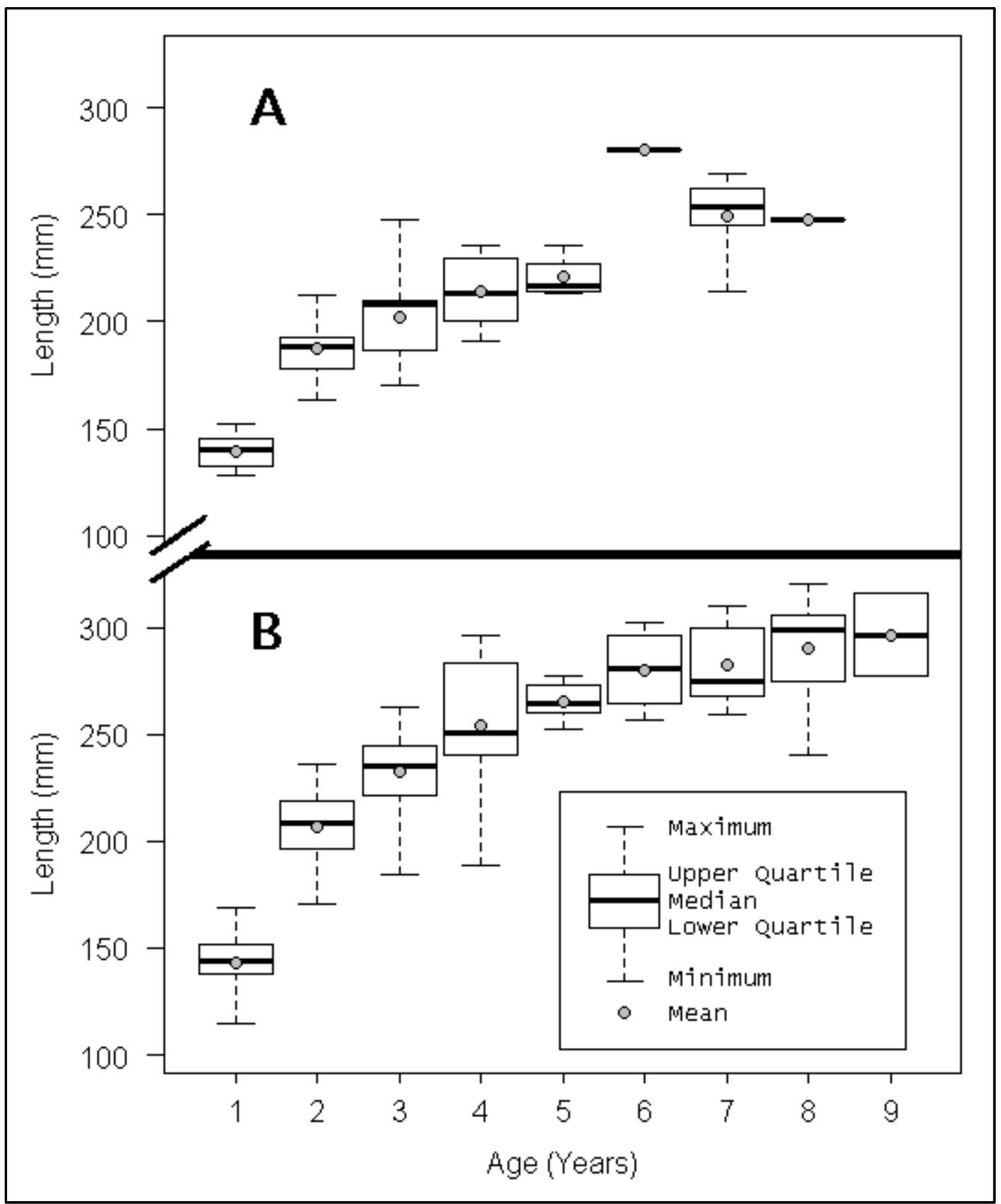

Figure 4. Length-at-age data collected from 57 male (A) and 175 female (B) yellow perch of Age-1 or older. 


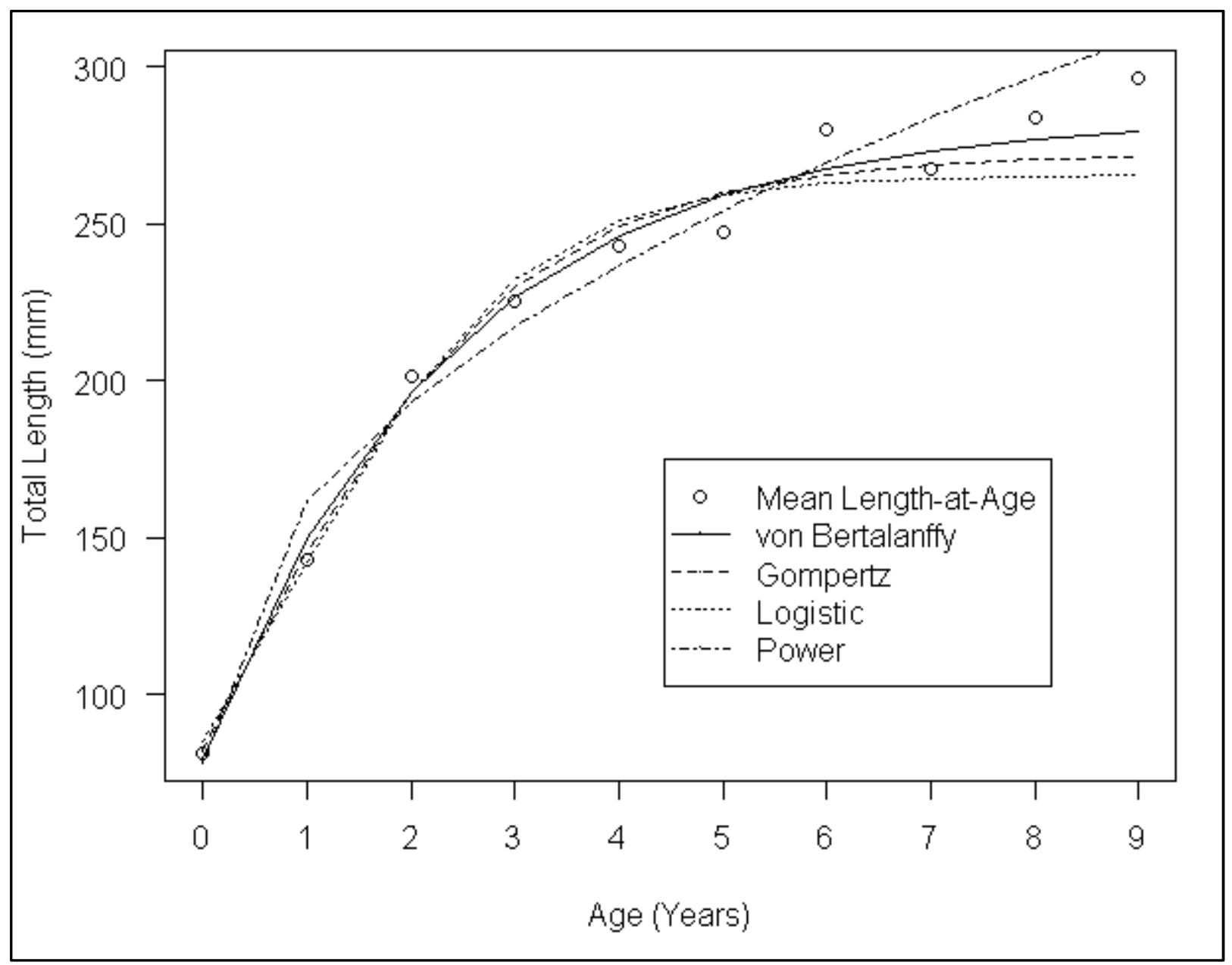

Figure 5. Comparison of growth models fitted to mean length-at-age data from 271 Cheat Lake yellow perch. 


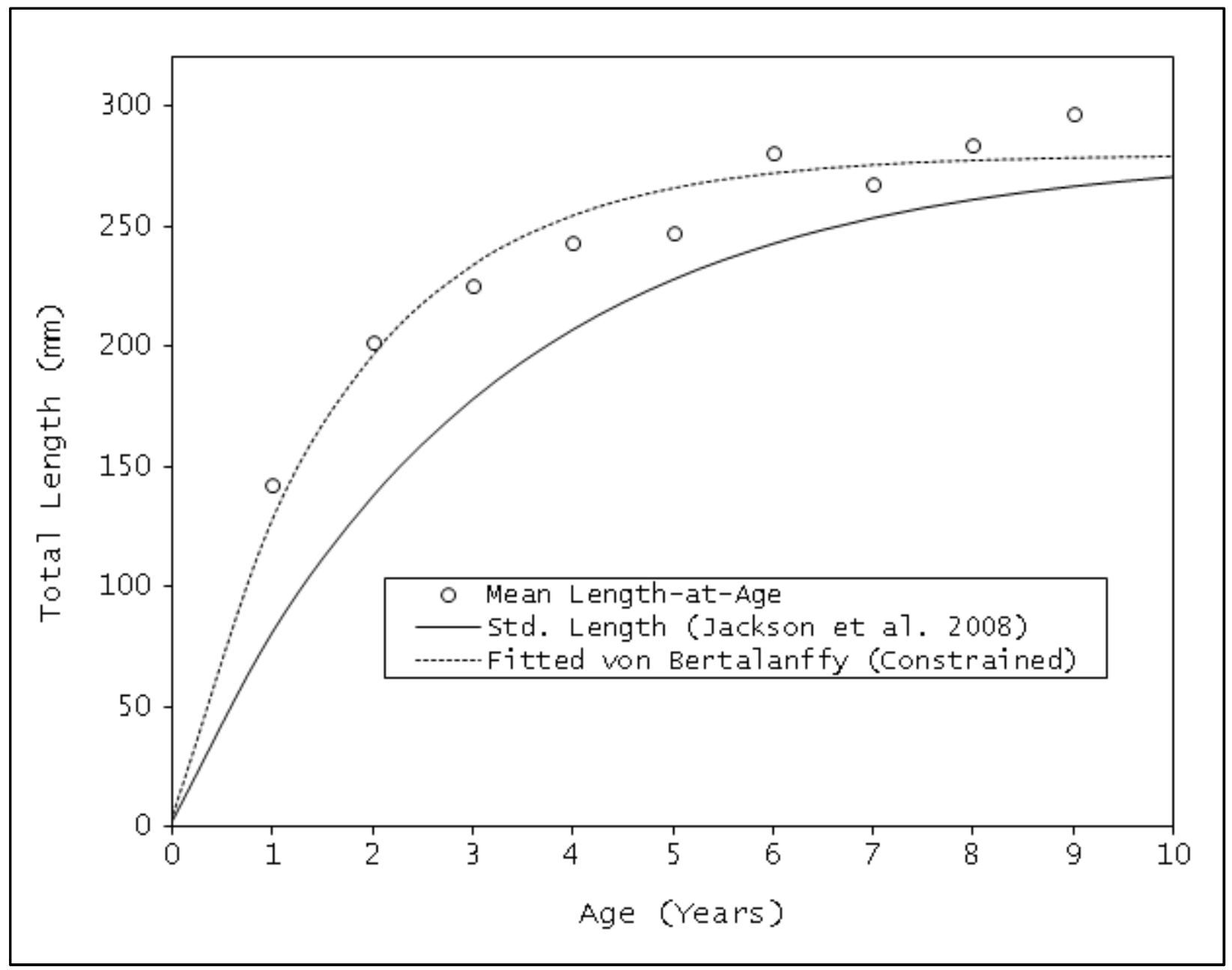

Figure 6. Comparison between growth rates of Cheat Lake yellow perch to the standard growth model (Jackson et al. 2008) representing typically growth patterns observed among all North American populations. Parameter $t_{0}$ constrained for fitted von Bertalanffy growth model for direct comparison. 


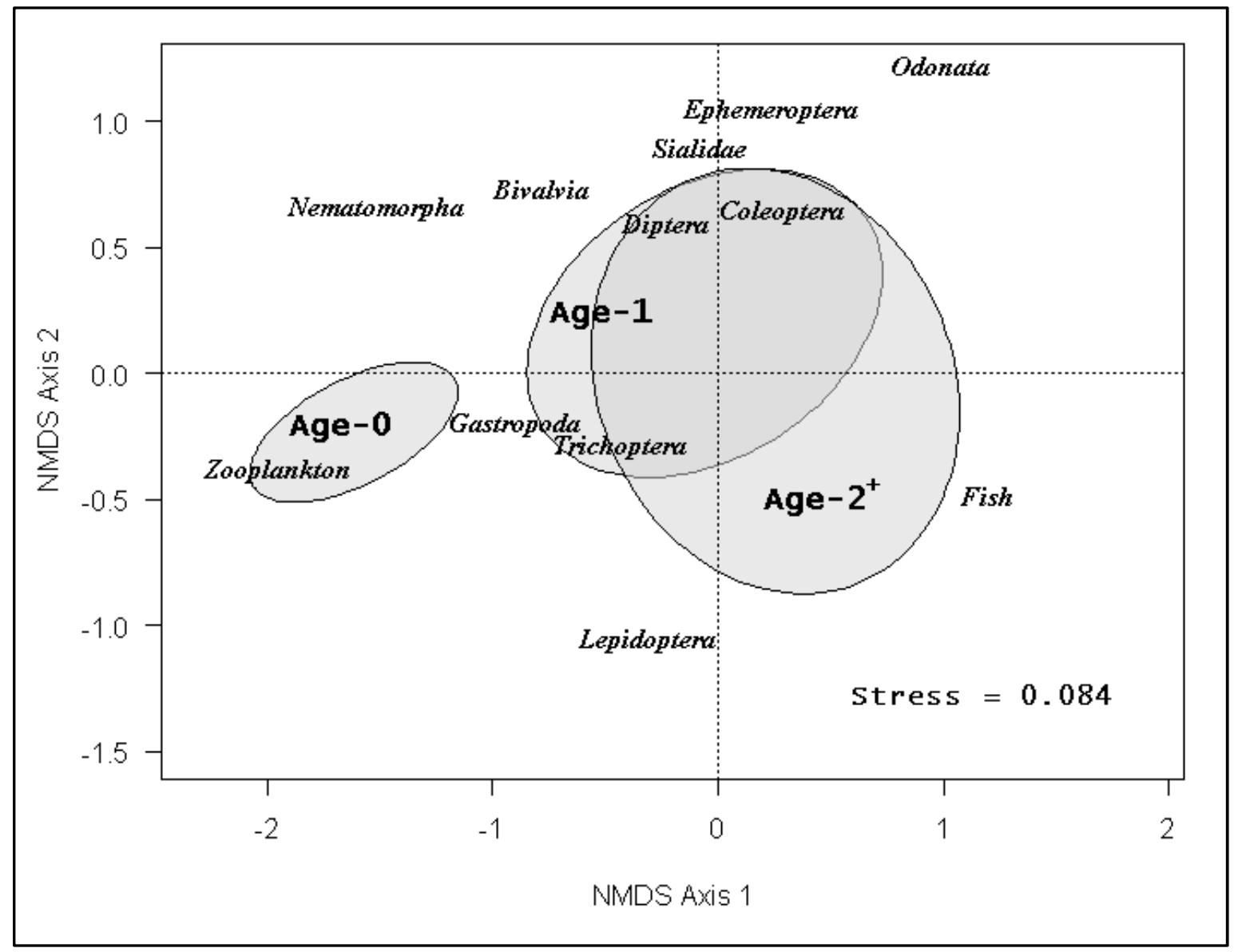

Figure 7. Ordination of summer diet composition among age groups. Ellipses represent $95 \%$ confidence intervals of mean NMDS scores age groups. 
